\title{
DNA taxonomy in morphologically plastic taxa: Algorithmic species delimitation in the Boodlea complex (Chlorophyta: Cladophorales)
}

\author{
Frederik Leliaert $^{\mathrm{a}, *}$, Heroen Verbruggen ${ }^{\mathrm{a}}$, Brian Wysor ${ }^{\mathrm{b}}$, Olivier De Clerck $^{\mathrm{a}}$ \\ ${ }^{a}$ Phycology Research Group and Center for Molecular Phylogenetics and Evolution, Biology Department, Ghent University, Krijgslaan 281 S8, 9000 Ghent, Belgium \\ ${ }^{\mathrm{b}}$ Department of Biology, Marine Biology and Environmental Science, Roger Williams University, 1 Old Ferry Road, Bristol, RI 02809, USA
}

\section{A R T I C L E I N F O}

\section{Article history:}

Received 26 December 2008

Revised 28 May 2009

Accepted 5 June 2009

Available online 11 June 2009

\section{Keywords:}

Cryptic species

DNA barcoding

nrDNA internal transcribed spacer

Green algae

Molecular phylogenetics

Morphological plasticity

Siphonocladales

Species boundaries

Ulvophyceae

\begin{abstract}
A B S T R A C T
DNA-based taxonomy provides a convenient and reliable tool for species delimitation, especially in organisms in which morphological discrimination is difficult or impossible, such as many algal taxa. A group with a long history of confusing species circumscriptions is the morphologically plastic Boodlea complex, comprising the marine green algal genera Boodlea, Cladophoropsis, Phyllodictyon and Struveopsis. In this study, we elucidate species boundaries in the Boodlea complex by analysing nrDNA internal transcribed spacer sequences from 175 specimens collected from a wide geographical range. Algorithmic methods of sequence-based species delineation were applied, including statistical parsimony network analysis, and a maximum likelihood approach that uses a mixed Yule-coalescent model and detects species boundaries based on differences in branching rates at the level of species and populations. Sequence analyses resulted in the recognition of 13 phylogenetic species, although we failed to detect sharp species boundaries, possibly as a result of incomplete reproductive isolation. We found considerable conflict between traditional and phylogenetic species definitions. Identical morphological forms were distributed in different clades (cryptic diversity), and at the same time most of the phylogenetic species contained a mixture of different morphologies (indicating intraspecific morphological variation). Sampling outside the morphological range of the Boodlea complex revealed that the enigmatic, sponge-associated Cladophoropsis (Spongocladia) vaucheriiformis, also falls within the Boodlea complex. Given the observed evolutionary complexity and nomenclatural problems associated with establishing a Linnaean taxonomy for this group, we propose to discard provisionally the misleading morphospecies and genus names, and refer to clade numbers within a single genus, Boodlea.
\end{abstract}

(c) 2009 Elsevier Inc. All rights reserved.

\section{Introduction}

Despite the wide acceptance of the idea that species represent a fundamental unit of biological organization (Mayr, 1982), there has been a great deal of disagreement with regard to the criteria used to delimit species. This disagreement has led to a proliferation of different species concepts, followed by endless discussions on their respective value and applicability (Mayden, 1997). More recently, however, important conceptual progress has been made in thinking about species concepts (de Queiroz, 1998, 2007). A vast majority of evolutionary biologists now accepts that species are lineages. Coincidentally, and albeit being controversial at first, DNA sequences are being increasingly used to identify species (DNA bar-

\footnotetext{
* Corresponding author. Address: Ghent University, Biology Department (WE11), Phycology Research Group, Krijgslaan 281, Building S8 (3rd floor), B-9000 Ghent, Belgium. Fax: +32 92648599 .

E-mail addresses: frederik.leliaert@ugent.be (F. Leliaert), heroen.verbruggen@_ ugent.be (H. Verbruggen), bwysor@rwu.edu (B. Wysor), olivier.declerck@ugent.be (O.D. Clerck).
}

coding, Hebert et al., 2003). With recent advances in methods for sequence-based species delimitation, formal analyses of species boundaries have become possible (Templeton, 2001; Sites and Marshall, 2003; Wiens, 2007; Zhang et al., 2008). Several methods for detecting species limits from DNA sequence data are based on diagnostic character variation. These methods, which are rooted in the phylogenetic species concept, aggregate a priori populations that lack discrete differences into a single species, which are distinguished from other species by unique nucleotide differences (Cracraft, 1983; Davis and Nixon, 1992; Wiens and Penkrot, 2002; Monaghan et al., 2005). Other procedures aim to detect discontinuities in sequence variation associated with species boundaries, assuming that clusters of closely related sequences that are preceded by long branches are suggestive for genetic isolated entities (Hudson and Coyne, 2002). One of these methods, statistical parsimony (Templeton et al., 1992), separates groups of sequences into different networks if genotypes are connected by long branches that are affected by homoplasy. Recently proposed, maximum likelihood approaches aim to determine species boundaries statistically from sequence data by analysing the dynamics of lineage 

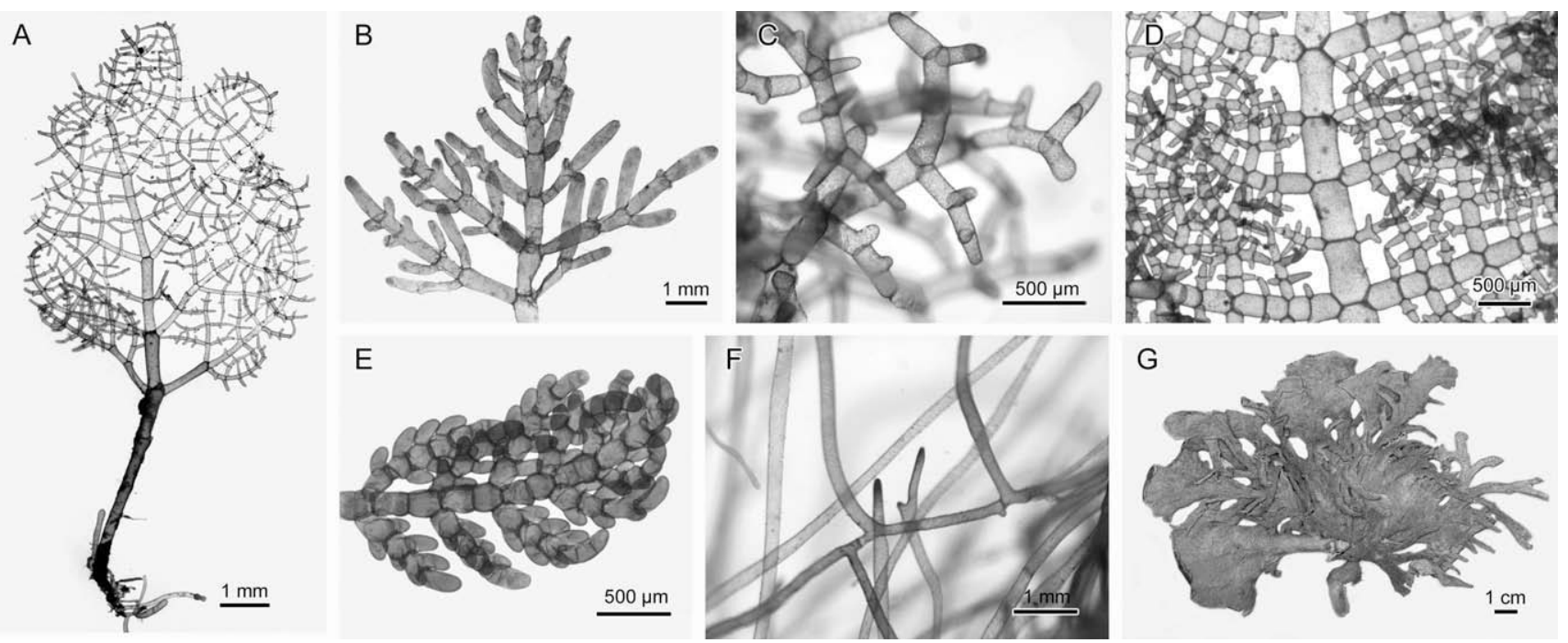

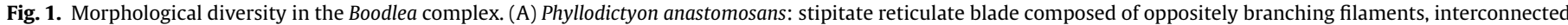

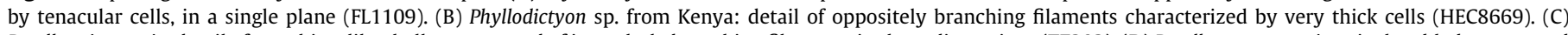

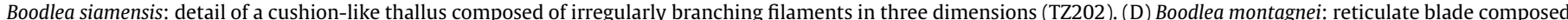

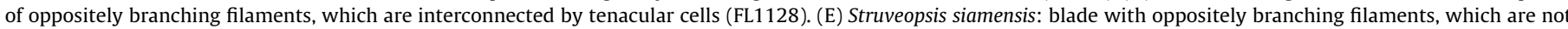

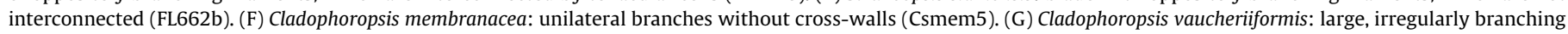
clump, composed of filaments associated with sponge tissue (HEC11394).

branching in phylogenetic trees, trying to determine the point of transition from species-level (speciation) to population-level (coalescent) evolutionary processes (Pons et al., 2006; Fontaneto et al., 2007).

Sequence-based species delimitation is particularly valuable in organisms in which morphological discrimination is difficult or impossible, such as in many algal groups (e.g., Saunders, 2005; Verbruggen et al., 2005, 2007; Harvey and Goff, 2006; Lilly et al., 2007; Vanormelingen et al., 2007). A group with a notorious long history of confusing species circumscriptions is the Boodlea complex, comprising the marine siphonocladalean green algal genera Boodlea, Cladophoropsis, Phyllodictyon and Struveopsis (Harvey,

Table 1

Survey of diagnostic features in the 13 recognized morphotypes.

\begin{tabular}{|c|c|c|c|c|c|}
\hline Morphological group & Thallus architecture & Branches & $\begin{array}{l}\text { Cross-wall at } \\
\text { branches }\end{array}$ & $\begin{array}{l}\text { Tenacular } \\
\text { cells }\end{array}$ & $\begin{array}{l}\text { Average diameter and length/ } \\
\text { width }(1 / w) \text { ratio of apical } \\
\text { cells }\end{array}$ \\
\hline 1. Boodlea composita & $\begin{array}{l}\text { Cushions composed of tightly } \\
\text { interwoven filaments }\end{array}$ & $\begin{array}{l}\text { Opposite, older cells producing } \\
\text { additional branches in three } \\
\text { dimensions }\end{array}$ & Present & Rare & $80 \mu \mathrm{m} \mathrm{l} / \mathrm{w}: 3$ \\
\hline $\begin{array}{l}\text { 2. Boodlea montagnei } \\
\text { (Fig. 1D) }\end{array}$ & Reticulate blades without stipes & $\begin{array}{l}\text { Opposite or single, regular, in a single } \\
\text { plane }\end{array}$ & Present & Abundant & $97 \mu \mathrm{m} \mathrm{l} / \mathrm{w}: 3$ \\
\hline $\begin{array}{l}\text { 3. Boodlea siamensis } \\
\text { (Fig. 1C) }\end{array}$ & $\begin{array}{l}\text { Cushions composed of tightly } \\
\text { interwoven filaments }\end{array}$ & $\begin{array}{l}\text { Opposite or single, older cells } \\
\text { producing additional branches in three } \\
\text { dimensions }\end{array}$ & Present & Abundant & $92 \mu \mathrm{m} \mathrm{l} / \mathrm{w}: 4$ \\
\hline $\begin{array}{l}\text { 4. Boodlea sp. } \\
\text { (Indonesia) }\end{array}$ & $\begin{array}{l}\text { Cushions borne on thick (c. } \\
600 \mu \mathrm{m} \text { ), erect, branched filaments }\end{array}$ & $\begin{array}{l}\text { Opposite or single, older cells } \\
\text { producing additional branches in three } \\
\text { dimensions }\end{array}$ & Present & Abundant & $110 \mu \mathrm{m} \mathrm{l} / \mathrm{w}: 3$ \\
\hline $\begin{array}{l}\text { 5. Cladophoropsis } \\
\text { macromeres }\end{array}$ & $\begin{array}{l}\text { Mats composed of loosely } \\
\text { entangled filaments }\end{array}$ & Single, unilaterally organized & Absent & Absent & $320 \mu \mathrm{m} \mathrm{l} / \mathrm{w}: 60$ \\
\hline $\begin{array}{l}\text { 6. Cladophoropsis } \\
\text { membranacea } \\
\text { (Fig. 1F) }\end{array}$ & $\begin{array}{l}\text { Cushions or mats composed of } \\
\text { tightly interwoven filaments }\end{array}$ & $\begin{array}{l}\text { Single, unilaterally or irregularly } \\
\text { organized }\end{array}$ & Absent & $\begin{array}{l}\text { Generally } \\
\text { absent }\end{array}$ & $185 \mu \mathrm{m} \mathrm{l} / \mathrm{w}: 45$ \\
\hline $\begin{array}{l}\text { 7. Cladophoropsis } \\
\text { philippinensis }\end{array}$ & $\begin{array}{l}\text { Cushions composed of loosely } \\
\text { entangled filaments }\end{array}$ & $\begin{array}{l}\text { Single or opposite, irregularly } \\
\text { organized }\end{array}$ & $\begin{array}{l}\text { Only present in } \\
\text { older branches }\end{array}$ & Absent & $510 \mu \mathrm{m} \mathrm{l} / \mathrm{w}: 40$ \\
\hline $\begin{array}{l}\text { 8. Cladophoropsis } \\
\text { sundanensis }\end{array}$ & $\begin{array}{l}\text { Cushions composed of tightly } \\
\text { interwoven filaments }\end{array}$ & $\begin{array}{l}\text { Single or opposite, irregularly } \\
\text { organized }\end{array}$ & $\begin{array}{l}\text { Occasionally } \\
\text { present }\end{array}$ & Absent & $90 \mu \mathrm{m} \mathrm{l} / \mathrm{w}: 35$ \\
\hline $\begin{array}{l}\text { 9. Cladophoropsis } \\
\text { vaucheriiformis } \\
\text { (Fig. 1G) }\end{array}$ & $\begin{array}{l}\text { Clumps of variable morphology, } \\
\text { associated with sponge tissue }\end{array}$ & $\begin{array}{l}\text { Generally single, irregularly organized } \\
\text { or filaments siphonous }\end{array}$ & $\begin{array}{l}\text { Occasionally } \\
\text { present }\end{array}$ & $\begin{array}{l}\text { Occasionally } \\
\text { present }\end{array}$ & $105 \mu \mathrm{m}$ l/w: 25 \\
\hline $\begin{array}{l}\text { 10. Phyllodictyon } \\
\text { anastomosans } \\
\text { (Fig. 1A) }\end{array}$ & Stipitate reticulate blades & $\begin{array}{l}\text { Generally opposite, regular, in a single } \\
\text { plane }\end{array}$ & Present & Abundant & $100 \mu \mathrm{m} \mathrm{l} / \mathrm{w}: 3$ \\
\hline $\begin{array}{l}\text { 11. Phyllodictyon sp. } \\
\text { (Kenya) (Fig. 1B) }\end{array}$ & Clustered stipitate blades & $\begin{array}{l}\text { Generally opposite, regular to } \\
\text { irregular, more or less in a single plane }\end{array}$ & Present & Rare & $310 \mu \mathrm{m} \mathrm{l} / \mathrm{w}: 5$ \\
\hline $\begin{array}{l}\text { 12. Siphonous sp. } \\
\text { (Florida) }\end{array}$ & Irregular cushion & Siphonous & Absent & Absent & $87 \mu \mathrm{m} \mathrm{l} / \mathrm{w}:-$ \\
\hline $\begin{array}{l}\text { 13. Struveopsis } \\
\text { siamensis (Fig. 1E) }\end{array}$ & $\begin{array}{l}\text { Stipitate blades. Stipes and basal } \\
\text { cells clavate with annular } \\
\text { constrictions }\end{array}$ & $\begin{array}{l}\text { Opposite, regular, more or less in a } \\
\text { single plane }\end{array}$ & Present & Absent & $160 \mu \mathrm{m} \mathrm{l} / \mathrm{w}: 3$ \\
\hline
\end{tabular}




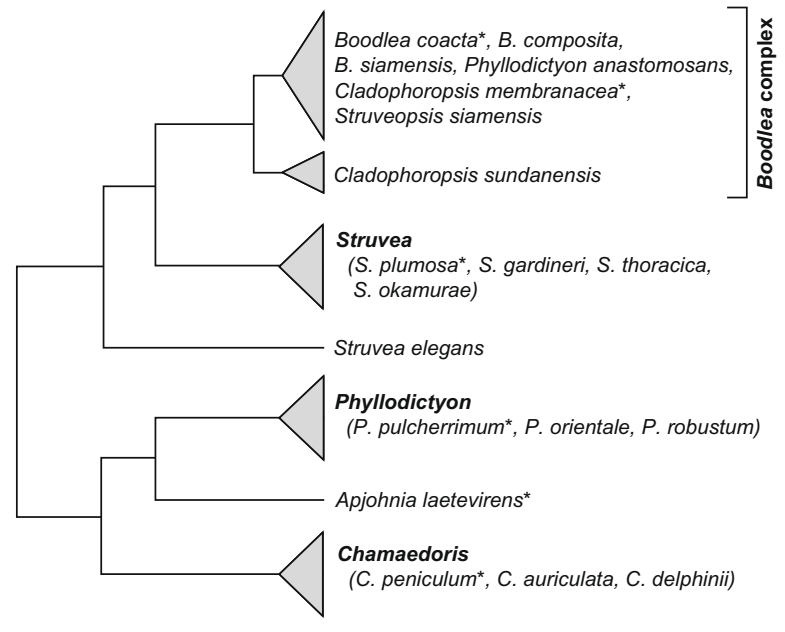

Fig. 2. Phylogenetic hypothesis of Boodlea and related genera based on Leliaert et al. (2007a,b, 2008). Taxa indicated by an asterisk represent generitypes.

1859; Egerod, 1975). These seaweeds are widely distributed along rocky coastlines and in coral reefs throughout the tropics and subtropics (Pakker et al., 1994). Previous taxonomic studies have attempted to delimit species based on the morphological species concept, seeking to recognize species by discontinuities in morphological characters such as thallus architecture, branching pattern, type of tenacular cells and cell dimensions (Fig. 1 and Table 1). More than 60 nominal species and infraspecific taxa have been formally described (14 in Boodlea, 36 in Cladophoropsis, 7 in Phyllodictyon and 5 in Struveopsis) (Index Nominum Algarum, 2008), but the relationships among these taxa were poorly understood. The number of morphospecies in the Boodlea complex was recently reduced to 13 by Leliaert and Coppejans (2006, 2007b). Analysis of morphological variation in this group was found to be problematic because many of the morphological features exhibit intraspecific variability to such an extent that generic boundaries are crossed.

Molecular phylogenetic studies have shown that most representatives of Boodlea, Cladophoropsis, Phyllodictyon and Struveopsis are closely related to the morphologically well defined genera Chamaedoris, Struvea and Apjohnia (Kooistra et al., 1993; Leliaert et al., 2003, 2007c). Within this clade, Phyllodictyon was shown to be non-monophyletic with $P$. anastomosans being more closely related to Boodlea than to the other Phyllodictyon species (including the type, $P$. pulcherrimum) (Leliaert et al., 2007a,b, 2008) (Fig. 2). Some other taxa are more distantly related; Boodlea vanbosseae Reinbold was found to be allied with Cladophora catenata (Linnaeus) Kützing, Anadyomene and Microdictyon (Leliaert et al., 2007b), while Cladophoropsis herpestica (Montagne) M.A. Howe falls within a clade of the Cladophora section Longi-articulatae (Leliaert et al., 2009).

Species boundaries in the Boodlea complex have remained uncertain because of low taxon sampling (Kooistra et al., 1993) or conservativeness of molecular markers (nuclear small and large subunit rDNA, Leliaert et al., 2007c). In a phylogeographic study, van der Strate et al. (2002) demonstrated that Cladophoropsis membranacea consists of at least three cryptic species with overlapping geographical distributions in the Atlantic Ocean, based on nrDNA internal transcribed spacer (ITS) sequence divergence, differential microsatellite amplification and thermal ecotypes. Biogeographic and systematic conclusions, however, were somewhat biased because only a single morphospecies was considered, and hence part of the genetic diversity within the species complex was overlooked.

In this study, we aim to elucidate species boundaries within the Boodlea complex based on nrITS sequences from 175 individuals sampled worldwide. Given the inherent difficulties of identifying species in this morphologically variable group of algae, we also sampled outside the known morphological bounds of the Boodlea complex, for example, including the sponge-associated Cladophoropsis (Spongocladia) vaucheriiformis. ITS sequences have been shown to provide good resolution at and below the species-level in a wide range of eukaryotic organisms, including siphonocladalean green algae (Bakker et al., 1992, 1995; van der Strate et al., 2002). Different methods of sequence-based species delineation were applied, including statistical parsimony network analysis, and a maximum likelihood approach, using the recently developed "general mixed Yule-coalescent" (GMYC) model, which detects species boundaries based on differences in branching rates at the level of species and populations.

\section{Materials and methods}

\subsection{Taxon sampling}

We sampled an extensive number of specimens (175) of the nominal species Boodlea composita, B. montagnei, B. siamensis, Cladophoropsis macromeres, C. membranacea, C. philippinensis, C. sundanensis, C. vaucheriiformis, P. anastomosans and Struveopsis siamensis from a broad geographical range (Table S1, online Supplementary material). Morphological species identification was based on differences in thallus architecture, presence of stipe cells, branching systems, timing of cross-wall formation, cell shape and dimensions, mode of thallus attachment and reinforcement, presence and morphology of tenacular cells, shape of crystalline cell inclusions, and cell wall thickness (Leliaert and Coppejans, 2006; 2007a,b). A number of plants could not be assigned to a described taxon: a siphonous Cladophoropsis-like specimen from Florida (designated as "siphonous sp."), three specimens from Indonesia with Cladophoropsis philippinensis-like basal filaments and terminal Boodlea-like branches ("Boodlea sp."), and a Phyllodictyon-like plant from Kenya with very large cells ("Phyllodictyon sp."). Collection of specimens and their preservation were carried out as described in Leliaert et al. (2007a). Published sequences from 42 isolates of Cladophoropsis membranacea (Kooistra et al., 1992; van der Strate et al., 2002) were also included. Voucher specimens from the latter study were kindly sent by Han van der Strate for morphological examination.

\subsection{Gene sampling and phylogenetic analyses}

Total genomic DNA was extracted from silica gel-dried specimens, herbarium material or from living plants in culture, and the target region, comprising nrDNA internal transcribed spacer regions (ITS1, ITS2) and the 5.8S rDNA, was amplified and sequenced as described in Wysor (2002) and Leliaert et al. (2007a,b). The Primer sequences are given in Table S2 (online Supplementary material). The 175 ITS sequences were aligned using MUSCLE (Edgar, 2004) via http://www.ebi.ac.uk/Tools/muscle/. The alignment (provided in a Supplementary online FASTA file) was straightforward and included a limited number of gaps. The amount of phylogenetic signal versus noise was assessed by calculating the $I_{\mathrm{ss}}$ statistic (a measure of substitution saturation in molecular phylogenetic datasets) with DAMBE v4.5.56 (Xia and Xie, 2001). Because nearly no variation was found within rDNA $5.8 \mathrm{~S}$ sequences, and because data of this region were unavailable for several isolates (van der Strate et al., 2002), this region was excluded for further analysis.

The dataset (ITS1-ITS2) was analysed with Bayesian inference (BI) and maximum likelihood (ML), using MrBayes v3.1.2 (Ronquist and Huelsenbeck, 2003) and PhyML v2.4.4 (Guindon and Gascuel, 
2003), respectively. The alignment was analysed under a general time-reversible model with and gamma distribution split into four categories (GTR + G4), as determined by the Akaike Information Criterion in PAUP/Modeltest 3.6 (Swofford, 2002; Posada and Crandall, 1998). BI consisted of two parallel runs each of four incrementally heated chains, and 3 million generations sampled every 1000 generations. The output was diagnosed for convergence using Tracer v.1.3 (Rambaut and Drummond, 2007a) and summary statistics and trees were generated using the last 2 million generations, well beyond the point at which convergence of parameter estimates had taken place. For the ML trees, the reliability of each internal branch was evaluated based on 1000 bootstrap replicates.

One of the species delimitation algorithms described below requires a chronometric phylogram (chronogram) in which branch lengths are roughly proportional to time. In order to obtain a chronogram, we applied molecular clock analyses to our data. First, the validity of a strict (uniform) molecular clock was tested using a likelihood ratio test by comparing the ML scores obtained with or without constraining a strict molecular clock in PAUP (Posada, 2003). A strict molecular clock was significantly rejected [ $\ln L$ without enforcing substitution rate constancy $=-18379.89$, compared to $\ln L$ with enforcing substitution rate constancy $=-18515.78$; $-2 \Delta \ln L=271.78, \chi^{2}$ statistic, d.f. (no. taxa -2$)=174, p=0.0000$ ]. Due to the violation of the strict molecular clock in our data, a relaxed molecular clock was used to estimate divergence times. More specifically, we applied the uncorrelated lognormal (UCLN) model (Drummond et al., 2006) implemented in BEAST v1.4.6 (Drummond and Rambaut, 2007). Two independent Markov chain Monte Carlo (MCMC) analyses were run for 7 million generations, sampling every 1000 . The output was diagnosed for convergence using Tracer v.1.3, and summary statistics and trees were generated using the last 5 million generations with TreeAnnotator (Rambaut and Drummond, 2007b). A logarithmic lineage-through-time plot of the ultrametric tree was generated using GENIE v3.0 (Pybus and Rambaut, 2002).

\subsection{Sequence-based species delimitation}

We applied two empirical methods for testing species boundaries. First, we aimed to detect discontinuities in sequence variation by using a statistical parsimony analysis, which partitions the data into independent networks of haplotypes connected by changes that are non-homoplastic with a 95\% probability (Templeton et al., 1992). Statistical parsimony networks were constructed with TCS 1.21 (Clement et al., 2000), with calculated maximum connection steps at $95 \%$ and with alignment gaps treated as missing data. In the second procedure changes in branching rates were tested at the species boundary in our chronogram following Pons et al. (2006). The method exploits the differences in the rate of lineage branching at the level of species and populations, recognizable as a sudden increase of apparent diversification rate when ultrametric node height is plotted against the number of nodes in a lineage-through-time plot. The procedure uses waiting times between successive branching events on an ultrametric tree as raw data. A combined model that separately describes population (a neutral coalescent model) and speciation (a stochastic birth-only or Yule model) processes, i.e., a general mixed Yule-coalescent (GMYC) model, is fitted on the ultrametric tree. The method optimizes a threshold position of switching from interspecific to intraspecific events such that nodes older than the threshold are considered to be diversification events (i.e., reflect cladogenesis generating the isolated species) and nodes younger than the threshold reflect coalescence occurring within each species. The number of shifts and their location on the phylogenetic tree provides the number of species and their relative age. A standard log-likelihood ratio test (comparing the likelihood for the mixed model to that ob- tained assuming a single branching process for the entire tree) is then used to assess if there is significant evidence for the predicted shift in branching rates. A confidence interval for the number of shifts is defined by $\pm 2 \log$ likelihood units which is expected to be $\chi^{2}$ distributed with $3^{\circ}$ of freedom. Model fitting and phylogenetic tests were performed using a script provided by T.G. Barraclough (Imperial College London), implemented in $R$ using functions of the APE library (Paradis et al., 2004).

\section{Results}

\subsection{Morphological groups}

Our dataset included 175 individuals distributed worldwide. We recognised 13 morphological entities based on differences in thallus architecture, branching system, cross-wall formation, cell dimensions, and presence or absence of tenacular cells (Table 1). These morphological groups correspond to 10 currently recognized species and three entities that could not be assigned to any previously described taxon. Most individuals could readily be assigned to one of the morphological entities. However, for a number of specimens unequivocal allocation to a single morphotype was problematic because of intermediate morphological features. These are indicated in Table S1 (online Supplementary material).

\subsection{Sequence analysis and phylogeny}

Visual inspection of the electropherograms of the nrITS sequences showed sequences with predominantly unambiguous peaks, indicating low intra-individual variation. The small number of ambiguities (or underlying peaks) constituted mainly single nucleotide polymorphisms that were not phylogenetically informative. Our observations are in agreement with cloning results in Cladophoropsis membranacea by van der Strate et al. (2002), who also found very low intra-individual polymorphism, including only autapomorphic point mutations. The ITS alignment of 175 sequences was 924 sites in total (ITS1: 439 sites, 5.8S: 157 sites and ITS2: 328 sites) and included 393 phylogenetic informative characters (ITS1: 226, 5.8S: 4 and ITS2: 163). For ITS1-ITS2 (excluding $5.8 \mathrm{~S})$, ML optimization carried out during the model selection procedure estimated nucleotide frequencies as $A=0.24, C=0.26$, $G=0.27$ and $T=0.23$. The best fit to the data was obtained with six substitution types and rates: $A C=0.72, A G=2.48, A T=1.28$, $C G=0.67, C T=2.48$, and $G T=1.00$, with among-site rate variation (gamma distribution shape parameter $=0.94$ ) and no separate rate class for invariable sites. In total, 92 ribotypes were present. Substitution saturation test (Xia and Xie, 2001) showed that the ITS dataset did not suffer from saturation $\left(I_{\mathrm{ss}}=0.146<I_{\mathrm{ss}} . \mathrm{C}=0.694\right.$, $p<0.001)$.

ML and BI yielded virtually identical tree topologies with comparable node support. The phylogenetic tree obtained from the ML analysis $(\ln L=-4895.76)$, with indication of ML bootstrap values and BI posterior probabilities, is shown in Fig. 3. Four main clades (A-D), separated by long internal branches with high support were recovered. The relaxed molecular clock analysis under a UCLN model yielded a virtual identical tree topology as the ML and BI analyses (Fig. 4).

\subsection{Sequence-based species delimitation}

Two algorithmic methods of sequence-based species delimitation were applied. In the first method, patterns of sequence variation were investigated for the presence of species-level groups by identifying independent networks using statistical parsimony (Templeton et al., 1992). This network analysis separated the total 
Genera (thallus morphology)

Cladophoropsis

(cushions or mats, unilateral branching, tenacula rare)

Boodlea

(3-dimensional reticulums, opposite branching, tenacula present)

Phyllodictyon

(stipitate reticulate blades, opposite branching, tenacula present)

- Struveopsis

(stipitate blades, opposite branching, tenacula absent)

cushion composed of siphonous branches,

irregular branching, tenacula absent

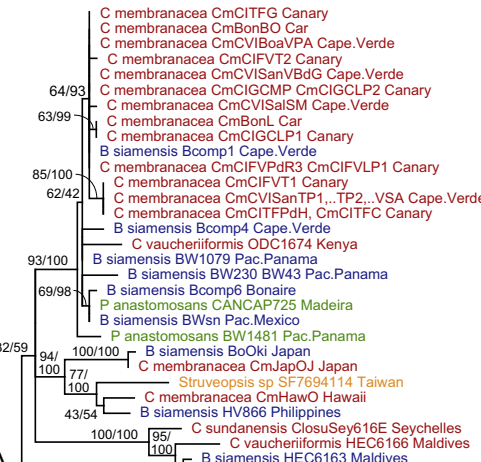

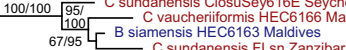

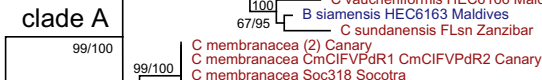
C membranacea CmRS2 Red.Sea

C membranacea CmMedSL Medi

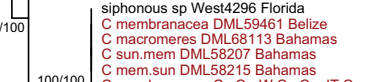

C sun.mem DML58207 Bahamas
C mem.sun DML58215 Bahamas

C membranacea CmCurW CmCurJT Car
C membranacea CmBont

C membranacea HVB87 Jamaica

C membranacea BW4 Car.Panam

C membranacea CmCVISalPdL2 Cape.Verde
- C membranacea CmCVISalPdL1 Cape.Verde

C C membranacea $\mathrm{CmMau}$ Mauritiania

98/100 C vaucherifformis FL954A,B Zanzibar

98/100 $P$ anastomosans FL1010 Zanzibar

89/100 ${ }_{99 / 100} P$ anastomosans FL $P$ anastomosans $F L$ s. 266,985 Zanzibar

( B composita FL923 Zanzibar

98/4 C vaucheriformis FL989 Zanzibar
100
C C vaucherifirormis HEC11135 Maffia

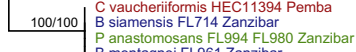

C P anastomosans FL994 FL980

100/100 $100 / 100$
B composita ODC665 Tanzania
B siamensis F F L99 Zanzibar
B composita FL950 Zanzibar

64/89 971 - B siamensis ODC1668 Kenya

100
B B composita FL702 Zanzibar

B composita FL FL2 Zanzibar
60/98 S S S Bamensis FL916 Tanzania

$57 / 100$
B compositas FL664 Zanzibar
B composita FL694B Zanzibar

$P$ anastomosans D D J6608 Ghana
$P$ anastomosans BWs Pac.Australi

100/100 P anastomosans DJ9274 Gambia

P anastomosans BWsn Florida
$P$ anastomosans SaMB StCrai

P anastomosans DML68772 Belize
B siamensis DML64212 Car.Panama

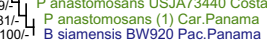

clade C

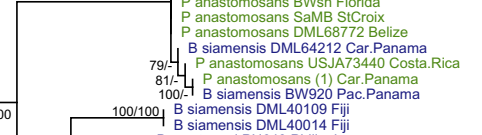

$\mathrm{P} 3$

$\mathrm{P} 2$
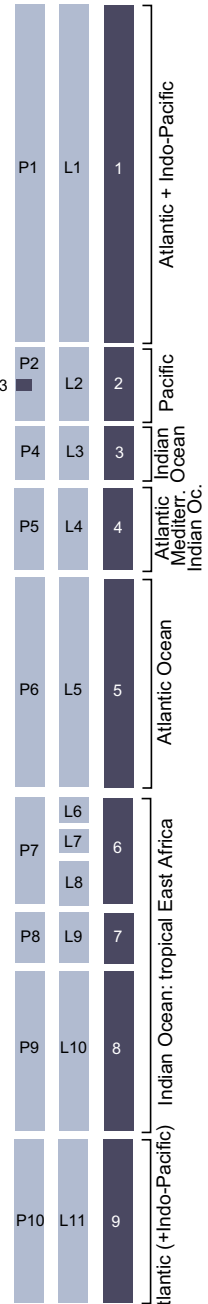

P11 L12 B montagnei PHML40014 Fiji IL $\begin{aligned} & \text { B montagnei PH648 Philipines } \\ & \text { B montagnei HV868 Philippines }\end{aligned}$ 55/100 100/100 $\begin{aligned} & \text { B montagnei FL1184 Philippines } \\ & \text { B montagnei P7646 Philippines }\end{aligned}$ - B montagnei PH467 Philippines

77/97 C C sp L0654203 Indonesia In L L $80 / 98$

100/100 P anastomosans BW304, 1078

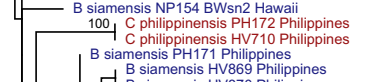

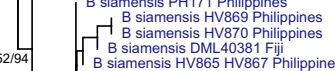
B siamensis HV865 HV867 Philippin
B siamensis SOC201 Socotra - Panastomosans CP13441 Papua B siamensis SOCC254 SOC204 SOC226 Socotra
B montagnei CP13133 Papua
B siamensis FL1090 FL1110 HV864 Philippines - B siamensis FL1122 Philippines B montagnei FL1089 Philippines P anastomosans FL1185 Philippines
P anastomosans FL1109 Philippines
B montagnei FL1111 Philippines

C 2976 Tanzania

clade D
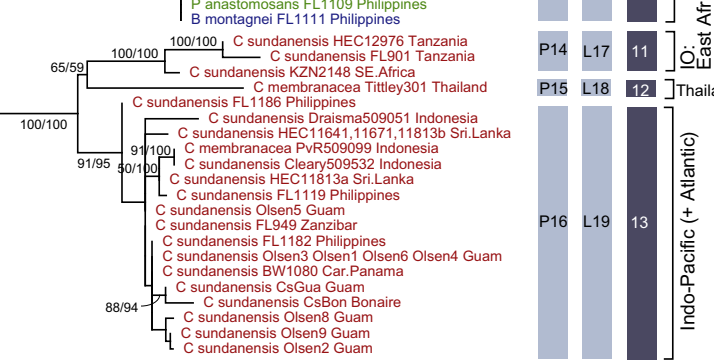

P14 1 17 11 ]

P15 L18 12 ]Thailand

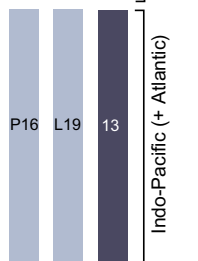

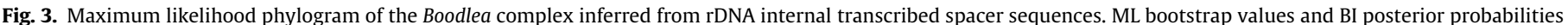

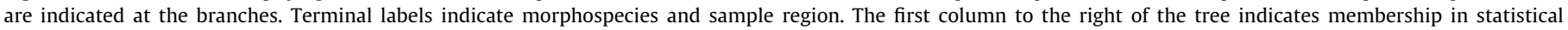

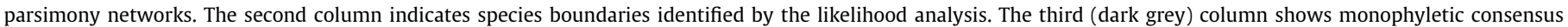

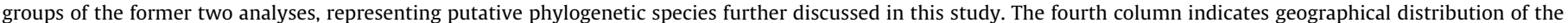

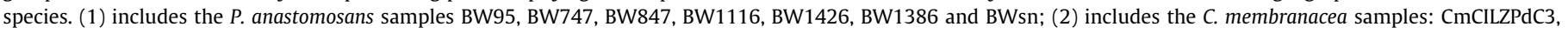
CmCILZPdC4, CmCILZPdC2, CmCILZPM, CmCILZPdC5 and CmCILZPdC1. 


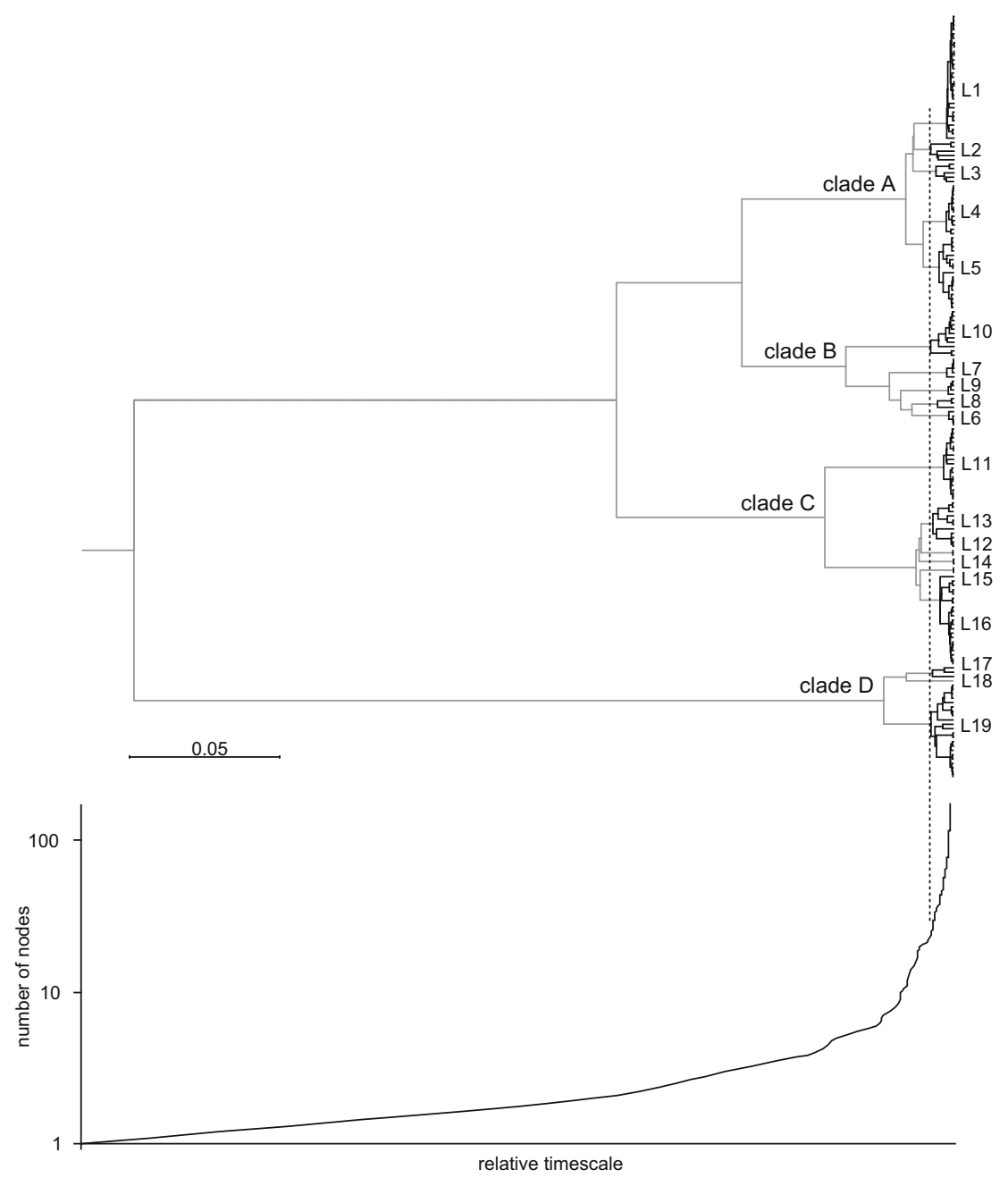

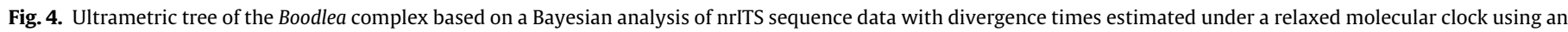

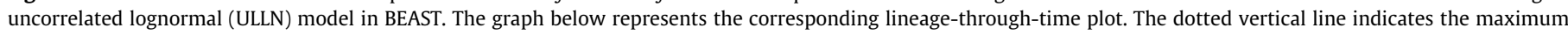
likelihood transition point of the switch in branching rates, as estimated by a general mixed Yule-coalescent (GMYC) model.

variation of ITS sequences into 16 groups based on a maximum connection limit of 12 steps (branches of 13 steps or more fell outside of the $95 \%$ confidence interval for non-homoplastic connections) (Fig. 3). Two groups were found to be nested within larger clades ( $\mathrm{p} 3$ within $\mathrm{p} 2$, and $\mathrm{p} 13$ within $\mathrm{p} 12$ ). In the second method,

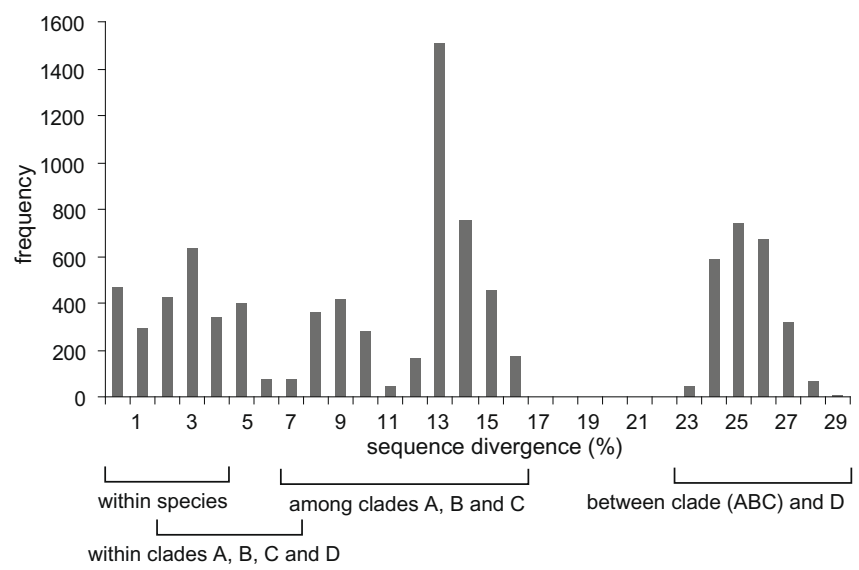

Fig. 5. Frequency distribution of pairwise genetic divergence (calculated as uncorrected $p$-distances) in the Boodlea complex. we analysed branch length dynamics to detect putative species. A logarithmic lineage-through-time plot showed a gradual-to-exponential increase in branching rate towards the present (Fig. 4). Fitting of the position of the speciation-to-coalescence transition using the GMYC model resulted in the identification of 19 putative species, which by and large corresponded with the groups identified by the network analysis (Fig. 3). Only in two cases was a single network (p7 and p12) split into different clusters. However, confidence limits (defined by $\pm 2 \log$ likelihood units) were extremely broad, nearly spanning the entire tree and resulting in a range of estimated number of species clusters from 1 to 30 . This high uncertainty was reflected in the test for significant clustering by comparing two models describing the likelihood of the branching pattern of the chronogram: (1) a null model that the entire sample derives from a single population following a neutral coalescence, and (2) a mixed (GMYC) model assuming a number of independently evolving species or populations joined by branching reflecting cladogenesis. The GMYC model was not favoured over the null model: $\log L=1610.727$, compared to null model: $\log L=1610.095$; $2 \Delta \log L=1.263, \chi^{2}$ test, d.f. $=3, p=0.738$. These results indicated that there is no significant evidence for the predicted shift in branching rates from interspecific to intraspecific events.

We took a conservative approach towards reconciling the results of the two algorithmic species delimitation methods. More specifically, we recognized only clades that received high clade 
Table 2

Distribution of the different morphotypes in the 13 phylogenetic species, defined in this study.

\begin{tabular}{|c|c|c|c|c|c|c|c|c|c|c|c|c|c|}
\hline \multirow[b]{2}{*}{ Morphotype } & \multicolumn{13}{|c|}{ Phylogenetic species } \\
\hline & 1 & 2 & 3 & 4 & 5 & 6 & 7 & 8 & 9 & 10 & 11 & 12 & 13 \\
\hline 1. Boodlea composita & & & & & & $\bullet$ & & $\bullet$ & & & & & \\
\hline 2. Boodlea montagnei & & & & & & & $\bullet$ & & & $\bullet$ & & & \\
\hline 3. Boodlea siamensis & $\bullet$ & $\bullet$ & $\bullet$ & & & & $\bullet$ & $\bullet$ & $\bullet$ & $\bullet$ & & & \\
\hline 4. Boodlea sp. (Indonesia) & & & & & & & & & & $\bullet$ & & & \\
\hline 5. Cladophoropsis macromeres & & & & & $\bullet$ & & & & & & & & \\
\hline 6. Cladophoropsis membranacea & $\bullet$ & $\bullet$ & & $\bullet$ & $\bullet$ & & & & & & & $\bullet$ & $\bullet$ \\
\hline 7. Cladophoropsis philippinensis & & & & & & & & & & $\bullet$ & & & \\
\hline 8. Cladophoropsis sundanensis & & & $\bullet$ & & & & & & & & $\bullet$ & & $\bullet$ \\
\hline 9. Cladophoropsis vaucheriiformis & $\bullet$ & & $\bullet$ & & & $\bullet$ & $\bullet$ & & & & & & \\
\hline 10. Phyllodictyon anastomosans & $\bullet$ & & & & & $\bullet$ & $\bullet$ & & $\bullet$ & $\bullet$ & & & \\
\hline 11. Phyllodictyon sp. (Kenya) & & & & & & & & $\bullet$ & & & & & \\
\hline 12. Siphonous sp. (Florida) & & & & & $\bullet$ & & & & & & & & \\
\hline 13. Struveopsis siamensis & & $\bullet$ & & & & & & & & & & & \\
\hline
\end{tabular}

support and were compatible with both the statistical parsimony and the maximum likelihood solution as species (Fig. 3). By compatible, we mean that the recognized species comprises one or more of the species inferred by the algorithm. This resulted in 13 clusters, which we recognized as putative phylogenetic species. As a general rule, node support between species clades was markedly larger than within the species. Sequence divergence (calculated as uncorrected $p$-distances) within these putative species ranged from complete identity to $4 \%$. Distances among species, within the main clades (A-D) ranged from $2 \%$ to $7 \%$ and among clades from $7 \%$ to $29 \%$ (Fig. 5, Table S3). A clear gap in sequence divergence was only noticeable between clade $D$ and clade $(A-C)$.

\subsection{Morphology and biogeography}

A striking observation was that isolates do not group based on their morphology. Most of the phylogenetic species include different morphotypes from a single or multiple genera, and at the same time, unique morphotypes are distributed in different clades of the phylogenetic tree (Fig. 3, Table 2). For example, representatives of Boodlea and Phyllodictyon are distributed in different species of clades A-C. Isolates with a Cladophoropsis sundanensis and C. membranacea morphology were recovered in the spp. 11 and 13 of clade $\mathrm{D}$, as well as in sp. 3 within clade A. The sponge-associated C. vaucheriiformis turns up in four species in clades A and B. A number of morphotypes, such as $C$. macromeres, $C$. philippinensis, $S$. siamensis and Phyllodictyon sp. (Kenya) are embedded in species along with other morphological forms. Despite the mixture of morphologies, it should be noted that some apparent morphological trends are detectable in our phylogeny. For example, clade A mainly includes samples with a $C$. membranacea morphology, while this morphospecies seems to be absent in clades B and C. The latter mainly includes Boodlea and Phyllodictyon morphologies. Clade D only includes Cladophoropsis-type morphologies.

A loose geographic pattern could be detected in our phylogeny (Figs. 3 and 6). Most species are largely or entirely restricted to either the Atlantic (spp. 1, 5 and 9) or Indo-Pacific basin (spp. 2, 3,10 and 13). Clade $C$ is separated into a largely Atlantic and Indo-Pacific subclade (corresponding to spp. 9 and 10). Remarkably, the entire clade B (spp. 6, 7 and 8) is restricted to the tropical East African coast. However, several of the clades (spp. 1, 4, 10, and 13) also harboured isolates from distant localities resulting in a much wider tropical distribution. Several examples of identical ITS ribotypes from distant regions in different oceans were found; for instance Madeira and Pacific Mexico (sp. 1, ca. 8900 km); Canary Islands, Red Sea and Socotra (sp. 4, ca. 8500 km); Guam and Tanzania (sp. 13, ca. 11,800 km), and Philippines, Guam and Caribbean Sea (sp. 13, ca. 17,000 km via the Pacific Ocean). Many species were found to occur sympatrically in various areas. Regions with high diversity include the NE Atlantic (including the African coast, the Canary and Cape Verde Islands, harbouring spp. 1, 4, 5 and 9), the Caribbean Sea (including spp. 1, 5, 9, 10 and 13) and the tropical East African coast (Kenya and Tanzania, with spp. 1, 3, 6, 7, 8, 11 and 13).

\section{Discussion}

\subsection{Sequence-based species delimitation}

Several quantitative methods for delimiting species based on DNA sequence data have been recently proposed. A number of commonly used procedures, including population aggregation analysis (Davis and Nixon, 1992), cladistic haplotype aggregation (Brower, 1999) and the Wiens-Penkrot methods (Wiens and Penkrot, 2002) aggregate populations lacking discrete differences into a single species. In these procedures, species are recognized based on fixed nucleotide differences unique to sets of populations, which are defined a priori based on morphological, geographical or ecological information. In our wide dataset, circumscription of initial groups based on morphological features is problematic because cryptic diversity and morphological variability are known to be present in the species complex (Leliaert and Coppejans, 2007b). Likewise, defining populations based on geographical or ecological data is difficult because cryptic species of Cladophoropsis membranacea have been shown to occur sympatrically in the same environments (van der Strate et al., 2002). We therefore opted to apply species delimitation methods that rely solely on sequence variation and do not require prior assumptions of population boundaries.

A dataset of nrITS sequences from 175 isolates was subjected to different procedures that aim to detect discontinuities in sequence variation associated with species boundaries. The first method for estimating these shifts included Templeton's statistical parsimony analysis, which partitions the variation into homoplastic (i.e., long branches) and non-homoplastic (short branches) variation (Templeton et al., 1992; Templeton, 2001). This method has been shown to separate groups of sequences that correspond to species in a number of studies (e.g., Cardoso and Vogler, 2005; Ahrens et al., 2007). The second method, recently developed by Pons et al. (2006), exploits the dynamics of lineage branching in a phylogenetic tree, aiming to detect a change in the rate of branching associated with the species boundary in a likelihood framework. Although, this approach did not show a sharp shift between species diversification (phylogeny) and coalescent processes (genealogy within species), the species boundaries suggested by this method 

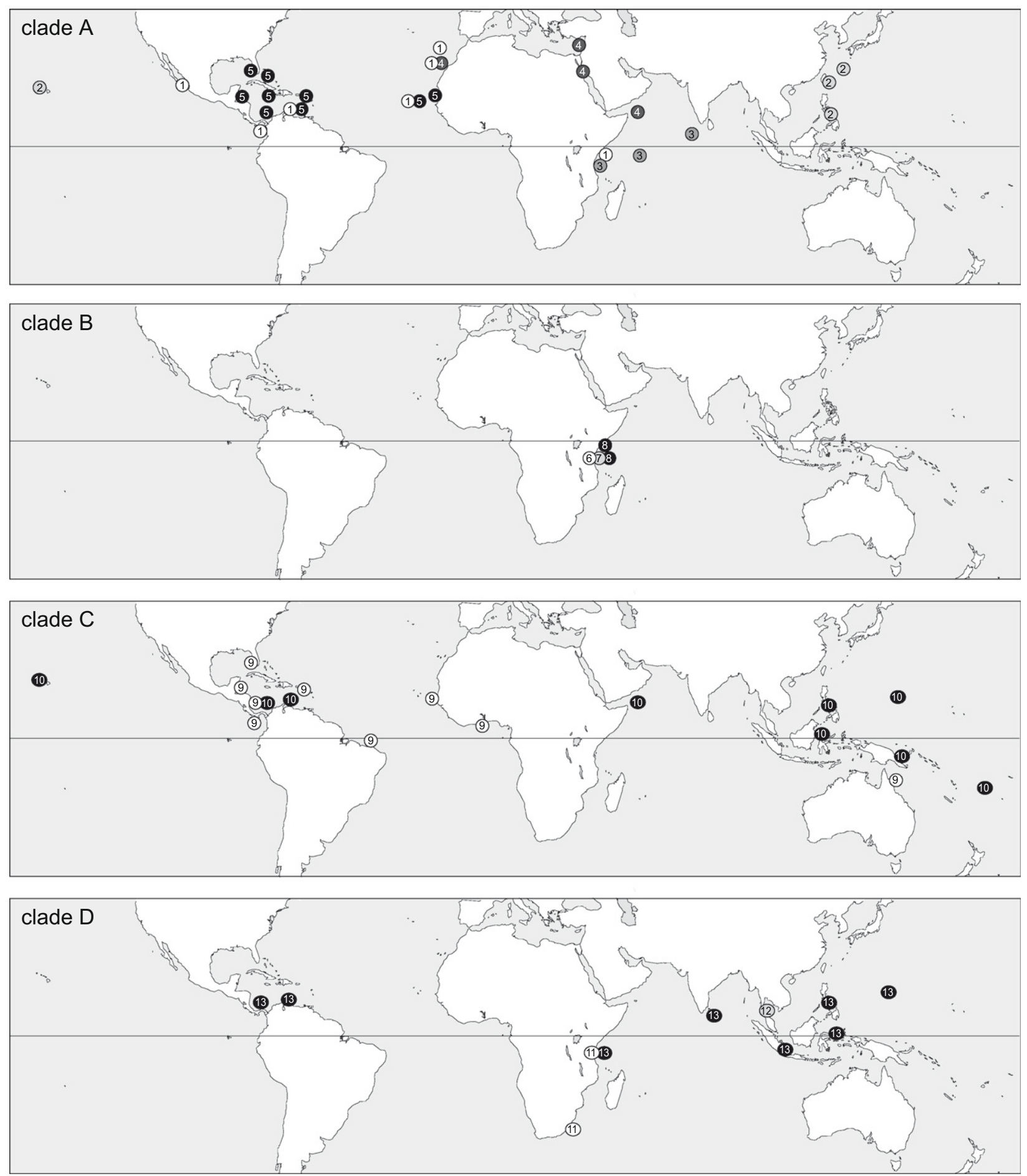

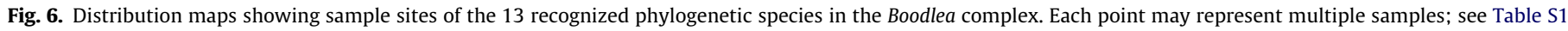
(online Supplementary material) for a complete listing.

were largely congruent with those of the statistical parsimony method (11 identical clusters). Where they differed, we identified clades that comprised one or more algorithmically defined species, that were separated using both methods and that received high support in the phylogeny. This resulted in the recognition of 13 species.

Failure to reject the null model (i.e., that of a single branching process for the entire tree) could have several interrelated explanations. First, the entire clade might represent a single, highly polymorphic species. A continuous, pantropical breeding population could be plausible given the high dispersal potential of Boodlea by thallus fragments that act as propagules (van den Hoek, 1987). However, this scenario is suspect, given that at least clades $B$ and D have also been clearly segregated based on SSU and LSU nrDNA sequence data (Leliaert et al., 2007a). Moreover, ITS sequence divergence within the entire clade exceeds $30 \%$, which is far outside the range of empirical levels of intraspecific divergence normally found in eukaryotes. Several studies have suggested low ITS variation (generally <8\%) to be indicative of biological species (Coleman, 2005, 2009; Casteleyn et al., 2008). Similar values have 
been implied in ulvophycean green algal species (Lindstrom and Hanic, 2005), including Cladophorales (Bakker et al., 1995). Within the morphospecies Cladophoropsis membranacea, species boundaries have been defined based on differential microsatellite amplification in combination with ITS sequence distances, which correlate with ecotypic differentiation in thermal tolerance (van der Strate et al., 2002). Intra-specific sequence divergence was found to be very low $(<0.4 \%)$ whereas divergence between species was much larger (2-3\%). Although, these levels of sequence divergence are similar to the ones found in this study, the discontinuity between intra- and interspecific divergence fades by increased taxon sampling. A second explanation for the lack of clear species limits is that the Boodlea complex comprises multiple incipient species, which form a continuum rather than discrete entities, because of incomplete reproductive isolation, or that formerly isolated species recently reverted to a continuous breeding population by hybridization (e.g., van Oppen et al., 2000). Incomplete reproductive isolation and hybridization events could account for the highly polymorphic ITS sequences in the Boodlea complex. This could be explained by the complex phylogeographic pattern in the Boodlea complex, showing a high degree of diversity in combination with genetic homogeneity (possibly as a result of occasional long distance dispersal events) over large spatial scales, resulting in a high degree of species co-occurrence. This hypothesis, however, remains to be tested.

Inability to detect a sharp species boundary based on ITS sequences might also be a direct consequence of intrinsic properties of the 18S-5.8S-26S nuclear ribosomal cistron, which is present in multiple copies in the nuclear genome. Various phenomena may generate intra-genomic variation of ITS sequences, creating problems for phylogenetic analysis and assumptions of orthology (reviewed in Alvarez and Wendel (2003); Nieto Feliner and Rosselló (2007)). van der Strate et al. (2002) and this study showed that intra-individual sequence variation was very low, and therefore did not affect phylogenetic reconstruction. The continuous variation of ITS sequences can also be a result of degradation of the ITS data at the species-level by recombination events between the multiple variants of interbreeding populations. The failure to reject the single branching process model for the entire tree may also be a result of violation of one of the assumptions in the GMYC model, namely, that of neutral coalescence of the nrITS sequences within species. Retained ancestral ITS polymorphism due to incomplete coalescence blur the transition between species-level and population-level branching processes. The possible lack of coalescence of the ITS sequences could be explained by the fact that speciation has been more rapid than concerted evolution of the multiple rDNA repeats. Species-level non-coalescence of ITS sequences has been demonstrated in various plants (e.g., in the Pine family, Wei et al., 2003; Campbell et al., 2005).

More loci, preferably from different genetic compartments will be needed to clarify species boundaries in the Boodlea complex. Several studies (e.g., Lane et al., 2007; Roy et al., 2009) have shown cases in which ITS failed to resolve clear species boundaries whereas non-recombinant DNA (e.g., plastid or mitochondrial markers) did give indications for genetic isolation. Analysis of multiple loci in siphonocladalean algae is problematic due to amplification problems of organellar DNA (as yet it has been impossible to amplify chloroplast or mitochondrial DNA in its members using standard primer combinations) and single-copy nuclear loci (as a consequence of the limited availability of genomic data for green algae and the omnipresence of large introns in their genes).

Various studies have emphasized the value of applying ITS2 RNA transcript secondary structure information for delimiting species. Coleman (2000) suggested that if two organisms differ with respect to a two-sided compensatory base pair change $(\mathrm{CBC})$, they belong to different biological species. Although, a common core of secondary structure of the ITS2 has been found throughout the eukaryotes (Schultz et al., 2005), representatives of Boodlea seem to form an exception to this rule. Distinct hallmarks of the conserved eukaryotic ITS2 structure are a central loop with four helices (of which helix III is the longest), the presence of a U-U mismatch in helix II and a UGGU motif in the $5^{\prime}$ side near the apex of helix III. All these features are missing in the various foldings of the Boodlea sequences. Moreover, we were not able to find an unequivocally conserved structure for all sequences in the Boodlea complex, complicating analyses of CBC's.

\subsection{Conflict between morphological and DNA-based species definitions}

Species within the genera Boodlea, Phyllodictyon, Struveopsis and Cladophoropsis have had a long history of confusing circumscriptions (Murray, 1889; Harvey, 1859; Egerod, 1975; Kooistra et al., 1993). Previous taxonomic studies have attempted to delimit species according to the morphological species concept, in which species are recognized by discrete morphological characters. However, evidence from field studies indicated that traditionally employed distinguishing characters such as growth form, branching patterns and cell dimensions show high levels of intraspecific variability, sometimes crossing generic boundaries (Leliaert and Coppejans, 2007b). Boodlea for example is traditionally distinguished from Phyllodictyon in the formation of three-dimensional cushion-like thalli lacking a stipe, while Phyllodictyon is characterized by netlike, stipitate blades. Some mature thalli of $P$. anastomosans however, have been found to form a three-dimensional reticulum without stipes. Some Boodlea species (e.g., B. montagnei and B. struveoides) on the other hand, do form monostromatic blades, and B. struveoides has been described as stipitate blades. Struveopsis siamensis differs from $P$. anastomosans and $B$. composita only by the lack of tenacular cells. As many as 60 taxa have been described, but this number was drastically reduced by Leliaert and Coppejans (2006, 2007b).

Our phylogenetic analyses show considerable conflict between species boundaries based on morphology or DNA sequences in the Boodlea complex. Under the assumption that the DNA-based species delimitation is correct, high levels of intraspecific morphological variability as well as high prevalence of cryptic diversity have led to an inappropriate morphological taxonomy. Most morphotypes appear in different molecular phylogenetic species. Hence, the traditional, morphology-based species circumscriptions in this group are untenable. None of the nominal taxa are valid species according the molecular phylogenetic species delimitation (de Queiroz and Donoghue, 1988). Cryptic diversity in Cladophoropsis membranacea has previously been detected based on ITS sequence data (van der Strate et al., 2002). However, because only a single morphological entity was considered, this study revealed only partial phylogenetic relationships. This phylogeny shows that $C$. membranacea does not form a monophyletic group but that it intermingles with dissimilar morphotypes, confirming the earlier study of Kooistra et al. (1993). Cryptic diversity has been reported in a wide range of eukaryotes, particularly in morphologically simple organisms, such as unicellular or filamentous green algae (Kooistra, 2002; Šlapeta et al., 2006). Verbruggen et al. (2009) discussed a potential link between thallus complexity and the prevalence and profundity of cryptic diversity. Although, our results partially supports this link (i.e., Boodlea thalli are morphologically simple), the Boodlea phylogeny reveals a more complex mixture of cryptic diversity and morphological variability.

Various factors, including phenotypic plasticity, developmental variability and polymorphism, may account for the observed intraspecific morphological variability. Phenotypic plasticity in the Boodlea complex has been demonstrated in culture studies, where 
changes in thallus architecture and branching pattern have be induced under different culture conditions. For example, the regularly opposite branching pattern of Phyllodictyon anastomosans has been found to change in a unilateral, Cladophoropsis-like branching pattern under low light and temperature conditions (Leliaert and Coppejans, 2006). The observation of intermediate morphologies between small Phyllodictyon-like plants and large Boodlea-like cushions during field studies are suggestive of developmental variability (Leliaert and Coppejans, 2007b). Polymorphism, possibly resulting from incomplete reproductive isolation and hybridization (as discussed above), offers another possible explanation for the observed infraspecific phenotypic variation.

\subsection{Association with sponges, over and over again}

Cladophoropsis vaucheriiformis, a species exclusively occurring in close association with sponges, is here revealed as an unusual member of the Boodlea complex. The species lives in association with halichondrine poriferans, resulting in tough, spongiose thalli ranging from prostrate mats to upright forms with finger-like processes (Leliaert and Coppejans, 2006; Kraft, 2007). The filaments and branches of this species often lack cross-walls, resulting in an apparently siphonous architecture (characteristic for bryopsidalean green algae). Because of this deviant morphology and anatomy, the species' systematic position has long been ambivalent. After being described as Spongocladia by Areschoug (1854), it was merged with Spongodendron by Murray and Boodle (1888) and finally transferred to Cladophoropsis by Papenfuss (1958). The data presented here show that various Indian Ocean isolates of $C$. vaucheriiformis belong to different clades along with specimens possessing typical Boodlea, Cladophoropsis or Phyllodictyon morphologies. This indicates that $C$. vaucheriiformis can be regarded as a growth form and that this algal-sponge association is not obligatory as previously thought (Papenfuss, 1950; Leliaert and Coppejans, 2006).

\subsection{Taxonomic consequences}

Our results call for radical taxonomic changes in this group of algae, including revised species definitions and a drastically different generic classification. As has been shown previously, Phyllodictyon anastomosans (including the taxonomic synonyms Struvea multipartita, $S$. delicatula and $S$. tenuis) is unrelated to the type of the genus (P. pulcherrimum) (Fig. 2) and should therefore be excluded from the genus (Leliaert et al., 2007a, 2008). Phyllodictyon anastomosans is clearly polyphyletic within the Boodlea complex and the taxon name is therefore untenable. Likewise, taxa of Cladophoropsis (type: C. membranacea) and Struveopsis (type: S. chagoensis C. Rhyne et $\mathrm{H}$. Robinson) are distributed in different clades within the Boodlea complex. The obvious nomenclatural solution would be to transfer all species names to the oldest generic name, Boodlea (Murray, 1889).

The complexity of genetic variation (the failure to detect a sharp species boundary) and morphological diversity (prevalence of infraspecific variation and cryptic diversity) in Boodlea exemplifies the difficulty of establishing a Linnaean taxonomy for this group. Similar problems have been discussed in other taxonomically complex groups of organisms, such as rapidly radiating lineages (Ennos et al., 2005; Monaghan et al., 2006; Cardoso et al., 2009). Although, this DNA-based species delimitation approach provides a reliable estimate of species diversity in the Boodlea complex, we feel that assigning Linnaean names to the sequence-based groups at this stage would be inappropriate because of their ambiguous species status. Additional markers, when they become available, could provide stronger support for species boundaries. In addition, due to incongruence of the traditional morphologically defined taxa with the DNA-based species, nomenclatural changes are problematic because of uncertain correspondence of the observed sequence variation with existing Linnaean binomials. In other words, it is presently impossible to provide taxon names for the 13 delimited phylogenetic species, because these species cannot be readily linked with nomenclatural types. Moreover, the phylogenetic position of a number of taxa (e.g., Cladophoropsis magna Womersley) remain uncertain (Leliaert and Coppejans, 2006). Future studies should aim to acquire DNA sequences from original type or topotype material.

As a practical solutions while these problems are being sorted out, we propose to temporarily discard the misleading morphospecies names, and refer to clade or species numbers within the Boodlea complex (Boodlea sp. 1, 2, etc.). Similar solutions have been proposed in other algal species complexes (e.g., Coffroth and Santos, 2005; Lilly et al., 2007).

\section{Acknowledgements}

We thank Eric Coppejans, Barrett Brooks, Stefano Draisma, Suzanne Fredericq, Wiebe Kooistra, Diane and Mark Littler, Jeanine Olsen, Willem Prud'homme van Reine, Wytze Stam and John West for collecting specimens or providing cultures. We are grateful to Caroline Vlaeminck for generating the sequence data. We thank Timothy Barraclough for providing the script implementing the GMYC model fitting. Matthias Wolf is acknowledged for confirming the aberrant RNA secondary structure of the ITS2. Phylogenetic analyses were carried out on the KERMIT computing cluster (Ghent University). Funding was provided by FWO-Flanders (research grants G.0142.05 and 1.5.218.08, and post-doctoral fellowship grants to FL, HV and ODC). BW was supported by a United States Information Agency Fulbright Fellowship and a Louisiana Board of Regents Doctoral Fellowship. Additional support was provided by a Mia J. Tegner Memorial Research Grant in Marine Environmental History from the Marine Conservation Biology Institute and DOE grant DEFGO2-997ER122220 awarded to Suzanne Fredericq. The Smithsonian Tropical Research Institute provided laboratory facilities and equipment as well as administrative support.

\section{Appendix A. Supplementary data}

Supplementary data associated with this article can be found, in the online version, at doi:10.1016/j.ympev.2009.06.004.

\section{References}

Ahrens, D., Monaghan, M.T., Vogler, A.P., 2007. DNA-based taxonomy for associating adults and larvae in multi-species assemblages of chafers (Coleoptera: Scarabaeidae). Mol. Phylogenet. Evol. 44, 436-449.

Alvarez, I., Wendel, J.F., 2003. Ribosomal ITS sequences and plant phylogenetic inference. Mol. Phylogenet. Evol. 29, 417-434.

Areschoug, J.E., 1854. Spongocladia, ett nytt algslägte. Öfversigt af Kongl. [Svenska] Vetenskaps-Akademiens Förhandlingar 10, 201-209.

Bakker, F.T., Olsen, J.L., Stam, W.T., 1995. Evolution of nuclear rDNA ITS sequences in the Cladophora albida/sericea clade (Chlorophyta). J. Mol. Evol. 40, 640-651.

Bakker, F.T., Olsen, J.L., Stam, W.T., van den Hoek, C., 1992. Nuclear ribosomal DNA internal transcribed spacer regions (ITS1 and ITS2) define discrete biogeographic groups in Cladophora albida (Chlorophyta). J. Phycol. 28, 839845 .

Brower, A.V.Z., 1999. Delimitation of phylogenetic species with DNA sequences: a critique of Davis and Nixon's population aggregation analysis. Syst. Biol. 48, 199-213.

Campbell, C.S., Wright, W.A., Cox, M., Vining, T.F., Major, C.S., Arsenault, M.P., 2005. Nuclear ribosomal DNA internal transcribed spacer 1 (ITS1) in Picea (Pinaceae): sequence divergence and structure. Mol. Phylogenet. Evol. 35, 165-185.

Cardoso, A., Vogler, A.P., 2005. DNA taxonomy, phylogeny and Pleistocene diversification of the Cicindela hybrida species group (Coleoptera: Cicindelidae). Mol. Ecol. 14, 3531-3546.

Cardoso, A., Serrano, A., Vogler, A.P., 2009. Morphological and molecular variation in tiger beetles of the Cicindela hybrida complex: is an 'integrative taxonomy' possible? Mol. Ecol. 18, 648-664. 
Casteleyn, G., Chepurnov, V.A., Leliaert, F., Mann, D.G., Bates, S.S., Lundholm, N., Rhodes, L., Sabbe, K., Vyverman, W., 2008. Pseudo-nitzschia pungens (Bacillariophyceae): a cosmopolitan diatom species? Harmful Algae 7, 241-257.

Clement, M., Posada, D., Crandall, K., 2000. TCS: a computer program to estimate gene genealogies. Mol. Ecol. 9, 1657-1660.

Coffroth, J.A., Santos, S.R., 2005. Genetic diversity of symbiotic dinoflagellates in the genus Symbiodinium. Protist 156, 19-34.

Coleman, A.W., 2000. The significance of a coincidence between evolutionary landmarks found in mating affinity and a DNA sequence. Protist 151, 1-9.

Coleman, A.W., 2005. Paramecium aurelia revisited. J. Eukaryot. Microbiol. 52, 6877.

Coleman, A.W., 2009. Is there a molecular key to the level of "biological species" in eukaryotes? A DNA guide. Mol. Phylogenet. Evol. 50, 197-203.

Cracraft, J., 1983. Species concept and speciation analysis. Curr. Ornith. 1, 159-187.

Davis, J.I., Nixon, K.C., 1992. Populations, genetic variation, and the delimitation of phylogenetic species. Syst. Biol. 41, 421-435.

de Queiroz, K., 1998. The general lineage concept of species, species criteria, and the process of speciation: a conceptual unification and terminological recommendations. In: Howard, D.J., Berlocher, S.H. (Eds.), Endless Forms: Species and Speciation. Oxford University Press, Oxford, pp. 57-75.

de Queiroz, K., 2007. Species concepts and species delimitation. Syst. Biol. 56, 879 886.

de Queiroz, K., Donoghue, M.J., 1988. Phylogenetic systematics and the species problem. Cladistics 4, 317-338.

Drummond, A.J., Rambaut, A., 2007. BEAST: Bayesian evolutionary analysis sampling trees. BMC Evol. Biol. 7, 214.

Drummond, A.J., Ho, S.W.Y., Phillips, M.J., Rambaut, A., 2006. Relaxed phylogenetics and dating with confidence. PLoS Biol. 4, 699-710.

Edgar, R.C., 2004. MUSCLE: a multiple sequence alignment method with reduced time and space complexity. BMC Bioinformatics 5, 113.

Egerod, L.E., 1975. Marine algae of the Andaman Sea coast of Thailand: Chlorophyceae. Bot. Mar. 18, 41-66.

Ennos, R.A., French, G.C., Hollingsworth, P.M., 2005. Conserving taxonomic complexity. Trends Ecol. Evol. 20, 164-168.

Fontaneto, D., Herniou, E.A., Boschetti, C., Caprioll, M., Melone, G., Ricci, C. Barraclough, T.G., 2007. Independently evolving species in asexual bdelloid rotifers. PLoS Biol. 5, 914-921.

Guindon, S., Gascuel, O., 2003. A simple, fast, and accurate algorithm to estimate large phylogenies by maximum likelihood. Syst. Biol. 52, 696-704.

Harvey, J.B.J., Goff, L.J.A., 2006. A reassessment of species boundaries in Cystoseirc and Halidrys (Phaeophyceae, Fucales) along the North American west coast. J Phycol. 42, 707-720.

Harvey, W.H., 1859. Phycologia Australica, vol. 2. Lovel Reeve \& Co., London.

Hebert, P.D.N., Cywinska, A., Ball, S.L., DeWaard, J.R., 2003. Biological identifications through DNA barcodes. Proc. R. Soc. B Biol. Sci. 270, 313-321.

Hudson, R.R., Coyne, J.A., 2002. Mathematical consequences of the genealogical species concept. Evolution 56, 1557-1565.

Index Nominum Algarum, University Herbarium, University of California, Berkeley. Compiled by Paul Silva. Available from: http://ucjeps.berkeley.edu/INA.htm [accessed 18 Dec 2008].

Kooistra, W., 2002. Molecular phylogenies of Udoteaceae (Bryopsidales, Chlorophyta) reveal nonmonophyly for Udotea, Penicillus and Chlorodesmis. Phycologia 41, 453-462.

Kooistra, W.H.C.F., Olsen, J.L., Stam, W.T., van den Hoek, C., 1993. Problems relating to species sampling in phylogenetic studies: an example of non-monophyly in Cladophoropsis and Struvea (Siphonocladales, Chlorophyta). Phycologia 32, 419428.

Kooistra, W.H.C.F., Stam, W.T., Olsen, J.L., van den Hoek, C., 1992. Biogeography of Cladophoropsis membranacea (Chlorophyta) based on comparisons of nuclear rDNA ITS sequences. J. Phycol. 28, 660-668.

Kraft, G.T., 2007. Algae of Australia. Marine Benthic Algae of Lord Howe Island and the Southern Great Barrier Reef, 1. Green Algae. Australian Biological Resources Study \& CSIRO Publishing, Canberra \& Melbourne.

Lane, C.E., Lindstrom, S.C., Saunders, G.W., 2007. A molecular assessment of northeast Pacific Alaria species (Laminariales, Phaeophyceae) with reference to the utility of DNA barcoding. Mol. Phylogenet. Evol. 44, 634-648.

Leliaert, F., Boedeker, C., Peña, V., Bunker, F., Verbruggen, H., De Clerck, O., 2009 Cladophora rhodolithicola sp. nov. (Cladophorales, Chlorophyta), a diminutive species from European maerl beds. Eur. J. Phycol. 44, 155-169.

Leliaert, F., Coppejans, E., 2006. A revision of Cladophoropsis Børgesen (Siphonocladales, Chlorophyta). Phycologia 45, 657-679.

Leliaert, F., Coppejans, E., 2007a. Systematics of two deep-water species from the Indo-West Pacific: Struvea gardineri A.Gepp \& E.Gepp and Phyllodictyon orientale (A.Gepp \& E.Gepp) Kraft \& M.J.Wynne (Siphonocladales, Chlorophyta). Bot. J. Linn. Soc 153, 115-132.

Leliaert, F., Coppejans, E., 2007b. Morphological re-assessment of the Boodled composita-Phyllodictyon anastomosans species complex (Siphonocladales: Chlorophyta). Australian Syst. Bot. 20, 161-185.

Leliaert, F., De Clerck, O., Verbruggen, H., Boedeker, C., Coppejans, E., 2007a Molecular phylogeny of the Siphonocladales (Chlorophyta: Cladophorophyceae). Mol. Phylogenet. Evol. 44, 1237-1256.

Leliaert, F., Huisman, J., Coppejans, E., 2007b. Phylogenetic position of Boodlea vanbosseae (Siphonocladales, Chlorophyta). Crypt. Algol. 28, 337-351.

Leliaert, F., Millar, A.J.K., Vlaeminck, C., Coppejans, E., 2007c. Systematics of the green macroalgal genus Chamaedoris Montagne (Siphonocladales), with an emended description of the genus Struvea Sonder. Phycologia 46, 709-725.
Leliaert, F., Rousseau, F., de Reviers, B., Coppejans, E., 2003. Phylogeny of the Cladophorophyceae (Chlorophyta) inferred from partial LSU rRNA gene sequences: is the recognition of a separate order Siphonocladales justified? Eur. J. Phycol. 38, 233-246.

Leliaert, F., Wysor, B., Verbruggen, H., Vlaeminck, C., De Clerck, O., 2008 Phyllodictyon robustum (Setchell et Gardner) comb. nov. (Siphonocladales, Chlorophyta), a morphologically variable species from the tropical Pacific coast of America. Crypt. Algol. 29, 217-233.

Lilly, E.L., Halanych, K.M., Anderson, D.M., 2007. Species boundaries and global biogeography of the Alexandrium tamarense complex (Dinophyceae). J. Phycol 43, 1329-1338.

Lindstrom, S.C., Hanic, L.A., 2005. The phylogeny of North American Urospora (Ulotrichales, Chlorophyta) based on sequence analysis of nuclear ribosomal genes, introns and spacers. Phycologia 44, 194-201.

Mayden, R.L., 1997. A hierarchy of species concepts: the denouement in the saga of the species problem. In: Claridge, M.F., Dawah, H.A., Wilson, M.R. (Eds.), Species: The Units of Biodiversity. Chapman and Hall, London, pp. 381-424.

Mayr, E., 1982. The Growth of Biological Thought: Diversity, Evolution and Inheritance. Belknap Press of Harvard University Press, Cambridge Massachusetts.

Monaghan, M.T., Balke, M., Gregory, T.R., Vogler, A.P., 2005. DNA-based species delineation in tropical beetles using mitochondrial and nuclear markers. Philos. Trans. R. Soc. Lond. B Biol. Sci. 360, 1925-1933.

Monaghan, M.T., Balke, M., Pons, J., Vogler, A.P., 2006. Beyond barcodes: complex DNA taxonomy of a south pacific island radiation. Proc. R. Soc. B Biol. Sci. 273, 887-893.

Murray, G., Boodle, L.A., 1888. On the structure of Spongocladia, Aresch. (Spongodendron, Zanard.), with an account of new forms. Ann. Bot. 2, 169-175

Murray, G., 1889. On Boodlea, a new genus of Siphonocladaceae. J. Linn. Soc. Lond. 25, 243-245.

Nieto Feliner, G., Rosselló, J.A., 2007. Better the devil you know? Guidelines for insightful utilization of nrDNA ITS in species-level evolutionary studies in plants. Mol. Phylogenet. Evol. 44, 911-919.

Pakker, H., Prud'homme van Reine, W.F., Breeman, A.M., 1994. Temperature responses and evolution of thermal traits in Cladophoropsis membranacea (Siphonocladales, Chlorophyta). J. Phycol. 30, 777-783.

Papenfuss, G.F., 1958. Notes on algal nomenclature. IV. Various genera and species of Chlorophyceae, Phaeophyceae and Rhodophyceae. Taxon 7, 104-109.

Papenfuss, G.F., 1950. On the identity of Spongocladia and Cladophoropsis. Pac. Sci. 4 208-213.

Paradis, E., Claude, J., Strimmer, K., 2004. APE: analyses of phylogenetics and evolution in R language. Bioinformatics 20, 289-290.

Pons, J., Barraclough, T.G., Gomez-Zurita, J., Cardoso, A., Duran, D.P., Hazell, S., Kamoun, S., Sumlin, W.D., Vogler, A.P., 2006. Sequence-based species delimitation for the DNA taxonomy of undescribed insects. Syst. Biol. 55 595-609.

Posada, D., Crandall, K.A., 1998. Modeltest: testing the model of DNA substitution. Bioinformatics 14, 817-818.

Posada, D., 2003. Selecting models of evolution. In: Vandamme, A.M., Salemi, M. (Eds.), The Phylogenetic Handbook. Cambridge University Press, Cambridge, pp. 256-282.

Pybus, O.G., Rambaut, A., 2002. GENIE: estimating demographic history from molecular phylogenies. Bioinformatics 18, 1404-1405.

Rambaut, A., Drummond, A.J., 2007a. Tracer. Availble from: http:// beast.bio.ed.ac.uk/tracer.

Rambaut, A., Drummond, A.J., 2007b. TreeAnnotator. Availble from: http:// beast.bio.ed.ac.uk/TreeAnnotator.

Ronquist, F., Huelsenbeck, J.P., 2003. MrBayes 3: Bayesian phylogenetic inference under mixed models. Bioinformatics 19, 1572-1574.

Roy, L., Dowling, A.P.G., Chauve, C.M., Buronfosse, T., 2009. Delimiting species boundaries within Dermanyssus Dugès 1834 (Acari:Dermanyssidae) using a total evidence approach. Mol. Phylogenet. Evol. 50, 446-470.

Saunders, G.W., 2005. Applying DNA barcoding to red macroalgae: a preliminary appraisal holds promise for future applications. Philos. Trans. R. Soc. Lond. B Biol. Sci. 360, 1879-1888.

Schultz, J., Maisel, S., Gerlach, D., Müller, T., Wolf, M., 2005. A common core of secondary structure of the internal transcribed spacer 2 (ITS2) throughout the Eukaryota. RNA 11, 361-364.

Sites, J.W., Marshall, J.C., 2003. Delimiting species: a renaissance issue in systematic biology. Trends Ecol. Evol. 18, 462-470.

Šlapeta, J., López-García, P., Moreira, D., 2006. Global dispersal and ancient cryptic species in the smallest marine eukaryotes. Mol. Biol. Evol. 23, 23-29.

Swofford, D.L., 2002. PAUP*. Phylogenetic Analysis Using Parsimony ("and Other Methods). Version 4. Sinauer Associates, Sunderland, Massachusetts.

Templeton, A.R., 2001. Using phylogeographic analyses of gene trees to test species status and processes. Mol. Ecol. 10, 779-791.

Templeton, A.R., Crandall, K.A., Sing, C.F., 1992. A cladistic analysis of phenotypic associations with haplotypes inferred from restriction endonuclease mapping and sequencing data. III. Cladogram estimation. Genetics 132, 619633.

van den Hoek, C., 1987. The possible significance of long-range dispersal for the biogeography of seaweeds. Helgol. Meeresunters. 41, 261-272.

van der Strate, H.J., Boele-Bos, S.A., Olsen, J.L., van de Zande, L., Stam, W.T., 2002. Phylogeographic studies in the tropical seaweed Cladophoropsis membranacea (Chlorophyta, Ulvophyceae) reveal a cryptic species complex. J. Phycol. 38, 572582 
van Oppen, M.J.H., Willis, B.L., vanVugt, H., Miller, D.J.M., 2000. Examination of species boundaries in the Acropora cervicornis group (Scleractinia, Cnidaria) using nuclear DNA sequence analysis. Mol. Ecol. 9, 1363-1373.

Vanormelingen, P., Hegewald, E., Braband, A., Kitschke, M., Friedl, T., Sabbe, K. Vyverman, W., 2007. The systematics of a small spineless Desmodesmus taxon, D. costato-granulatus (Sphaeropleales, Chlorophyceae), based on ITS2 rDNA sequence analyses and cell wall morphology. J. Phycol. 43, 378-396.

Verbruggen, H., De Clerck, O., Schils, T., Kooistra, W.H.C.F., Coppejans, E., 2005. Evolution and phylogeography of Halimeda section Halimeda. Mol. Phylogenet. Evol. 37, 789-803.

Verbruggen, H., Leliaert, F., Maggs, C.A., Shimada, S., Schils, T., Provan, J., Booth, D., Murphy, S., De Clerck, O., Littler, D.S., Littler, M.M., Coppejans, E., 2007. Species boundaries and phylogenetic relationships within the green algal genus Codium (Bryopsidales) based on plastid DNA sequences. Mol. Phylogenet. Evol. $44,240-254$.

Verbruggen, H., Vlaeminck, C., Sauvage, T., Sherwood, A.R., Leliaert, F., De Clerck, O. 2009. Phylogenetic analysis of Pseudochlorodesmis strains reveals cryptic diversity above the family level in the siphonous green algae (Bryopsidales, Chlorophyta). J. Phycol. 45, 726-731.

Wei, X.X., Wang, X.Q., Hong, D.Y., 2003. Marked intragenomic heterogeneity and geographical differentiation of nrDNA ITS in Larix potaninii (Pinaceae). J. Mol. Evol. 57, 635-637.

Wiens, J.J., Penkrot, T.A., 2002. Delimiting species using DNA and morphological variation and discordant species limits in spiny lizards (Sceloporus). Syst. Biol. 51, 69-91.

Wiens, J.J., 2007. Species delimitation: new approaches for discovering diversity. Syst. Biol. 56, 875-878.

Wysor, B., 2002. Biodiversity and biogeography of marine green algae of the Republic of Panama. Ph.D. Dissertation, University of Louisiana, Lafayette, p. 291.

Xia, X., Xie, Z., 2001. DAMBE: data analysis in molecular biology and evolution. J. Hered. 92, 371-373.

Zhang, A.B., Sikes, D.S., Muster, C., Li, S.Q., 2008. Inferring species membership using DNA sequences with back-propagation neural networks. Syst. Biol. 57, 202-215. 
Appendix A. Supplementary data

Table S1

List of specimens, sorted by phylogenetic species as delimited in Fig. 3.

\begin{tabular}{|c|c|c|c|c|}
\hline $\begin{array}{l}\text { Phylogenetic } \\
\text { species }\end{array}$ & Morphological group & Specimen number & Geographical origin (collector and date of collection) & $\begin{array}{l}\text { Genbank accession } \\
\text { number }\end{array}$ \\
\hline \multirow[t]{26}{*}{ sp. 1} & Boodlea siamensis / composita & Bcomp1.F248 & Cape Verde Islands: San Vicente, San Andres (H. Pakker, 1991) & FN377604 \\
\hline & Boodlea siamensis / composita & Bcomp4.F250 & Cape Verde Islands: San Tiago, Tarrafal (H. Pakker, 1991) & FN377606 \\
\hline & Boodlea siamensis / composita & Bcomp6.F251 & Bonaire: Bonaire, Karpata (1991) & FN377603 \\
\hline & Boodlea siamensis & BW1079 & Panama: Isla Grande (Caribbean) (B. Wysor, 7-Oct-1999) & AF510115 \\
\hline & Boodlea siamensis & BW230 & Panama: Isla Culebra, Panama City (Pacific) (B. Wysor, 1-Apr-1999) & AF510114 \\
\hline & Boodlea siamensis & BW43 & Panama: Isla Culebra, Panama City (Pacific) (B. Wysor, 18-Feb-1999) & AF510113 \\
\hline & Boodlea siamensis & BWsn & Mexico: Mexico, Lo de Marcos, Nayarit (Pacific) (Mendoza-Gonzalez, 12-Sep-2001) & AF510117 \\
\hline & Phyllodictyon anastomosans & CANCAP725 & Madeira: Spain, Porto Santo, Madeira (Cancap3, 7-Oct-1978) & AF510116 \\
\hline & Cladophoropsis membranacea & CmBonL & Bonaire: Lagun (Caribbean) (H. van der Strate, Feb-1997) & AY055872.AY055939 \\
\hline & Cladophoropsis membranacea & CmCIFVLP1 & Canary Islands: Fuerteventura, Las Playitas (H. van der Strate, Jan-1998) & AY055904.AY055989 \\
\hline & Cladophoropsis membranacea & CmCIFVPdR3 & Canary Islands: Fuerteventura, Punta del Rincón (H. van der Strate, Jan-1998) & AY055902.AY055983 \\
\hline & Cladophoropsis membranacea & CmCIFVT1 & Canary Islands: Fuerteventura, Tarajalejo (H. van der Strate, Jan-1998) & AY055897.AY055974 \\
\hline & Cladophoropsis membranacea & CmCIFVT2 & Canary Islands: Fuerteventura, Tarajalejo (H. van der Strate, Jan-1998) & AY055898.AY055975 \\
\hline & Cladophoropsis membranacea & CmCIGCLP1 & Canary Islands: Gran Canaria, Las Palmas (H. van der Strate, Jan-1998) & AY055923.AY056014 \\
\hline & Cladophoropsis membranacea & CmCIGCLP2 & Canary Islands: Gran Canaria, Las Palmas (H. van der Strate, Jan-1998) & AY055924.AY056015 \\
\hline & Cladophoropsis membranacea & CmCIGCMP & Canary Islands: Gran Canaria, Faro de Maspalomas (H. van der Strate, Jan-1998) & AY055925.AY056016 \\
\hline & Cladophoropsis membranacea & CmCITFC & Canary Islands: Tenerife, Candelaria (H. van der Strate, Jan-1998) & AY055905.AY055990 \\
\hline & Cladophoropsis membranacea & CmCITFG & Canary Islands: Tenerife, Garachico (H. van der Strate, Jan-1998) & AY055909.AY055996 \\
\hline & Cladophoropsis membranacea & CmCVIBoaVPA & Cape Verde Islands: Boa Vista, Ponta Antonia, Derrubado (H. van der Strate, Jul-1998) & AY055893.AY055970 \\
\hline & Cladophoropsis membranacea & CmCVISalSM & Cape Verde Islands: Sal, Santa Maria (H. van der Strate, Jul-1998) & AY055895.AY055972 \\
\hline & Cladophoropsis membranacea & CmCVISanTP1 & Cape Verde Islands: São Tiago, Praia (H. van der Strate, Jul-1998) & AY055884.AY055954 \\
\hline & Cladophoropsis membranacea & CmCVISanTP2 & Cape Verde Islands: São Tiago, Praia (H. van der Strate, Jul-1998) & AY055885.AY055955 \\
\hline & Cladophoropsis membranacea & CmCVISanVBdG & Cape Verde Islands: São Vicente, B. de Gattas (H. Pakker, 1991) & AY055894.AY055971 \\
\hline & Cladophoropsis membranacea & CmCVISanVBdG.F291 & Cape Verde Islands: B. de Gattas, San Vicente (H. Pakker, 1991) & FN377605 \\
\hline & Cladophoropsis membranacea & CmCVISanVSA & Cape Verde Islands: São Vicente, San Andres (H. van der Strate, Jul-1998) & AY055886.AY055956 \\
\hline & Cladophoropsis vaucheriiformis & ODC1674.F849 & Kenya: Chale Island (O. De Clerck, 5-Apr-2008) & FN377607 \\
\hline \multirow[t]{5}{*}{ sp. 2} & Boodlea siamensis & BoOki & Japan: Okinawa Jima (M. Chihara) & Kooistra et al. 1993 \\
\hline & Cladophoropsis membranacea & $\mathrm{CmHawO}$ & Hawaii: Oahu & AY055860.AY055927 \\
\hline & Cladophoropsis membranacea & CmJapOJ & Japan: Okinawa Jima & AY055859.AY055926 \\
\hline & Boodlea siamensis & HV866.F345 & Philippines: Mactan Island (H. Verbruggen, 16-Feb-2004) & FN377608 \\
\hline & Struveopsis sp & SF7694114 & Taiwan: Magang Harbor (S. Frederiq and S.-M Lin, 6-Jul-1994) & AF510119 \\
\hline \multirow[t]{5}{*}{ sp. 3} & Cladophoropsis sundanensis & ClosuSey616E.F282 & Seychelles: Poivre Atoll (W. Kooistra, 1993) & FN377610 \\
\hline & Cladophoropsis sundanensis & ClosuSey616E.F415 & Seychelles: Poivre Atoll (W. Kooistra, 1993) & FN377611 \\
\hline & Cladophoropsis sundanensis & FLsn1 & Tanzania: Zanzibar, Nungwi (F. Leliaert, 21-Jul-2001) & FN377609 \\
\hline & Boodlea siamensis & HEC6163.F668 & Maldives: South Male Atoll, Biyadoo (E. Coppejans, 7-Apr-1986) & FN377612 \\
\hline & Cladophoropsis vaucheriiformis & HEC6166.F669 & Maldives: South Male Atoll, Biyadoo (E. Coppejans, 8-Apr-1986) & FN377613 \\
\hline
\end{tabular}


Table S1 (continued)

\begin{tabular}{|c|c|c|c|c|}
\hline $\begin{array}{l}\text { Phylogenetic } \\
\text { species }\end{array}$ & Morphological group & Specimen number & Geographical origin (collector and date of collection) & $\begin{array}{l}\text { Genbank accession } \\
\text { number }\end{array}$ \\
\hline \multirow[t]{10}{*}{ sp. 4} & Cladophoropsis membranacea & CmCIFVPdR1 & Canary Islands: Fuerteventura, Punta del Rincón (H. van der Strate, Jan-1998) & AY055899.AY055976 \\
\hline & Cladophoropsis membranacea & CmCIFVPdR2 & Canary Islands: Fuerteventura, Punta del Rincón (H. van der Strate, Jan-1998) & AY055900.AY055977 \\
\hline & Cladophoropsis membranacea & CmCILZPdC1 & Canary Islands: Lanzarote, Puerto del Carmen (H. van der Strate, Jan-1998) & AY055922.AY056013 \\
\hline & Cladophoropsis membranacea & CmCILZPdC2 & Canary Islands: Lanzarote, Carmen (H. van der Strate, Jan-1998) & AY055911.AY055998 \\
\hline & Cladophoropsis membranacea & CmCILZPdC4 & Canary Islands: Lanzarote, Carmen (H. van der Strate, Jan-1998) & AY055919.AY056010 \\
\hline & Cladophoropsis membranacea & CmCILZPdC5 & Canary Islands: Lanzarote, Carmen (H. van der Strate, Jan-1998) & AY055921.AY056012 \\
\hline & Cladophoropsis membranacea & CmCILZPM & Canary Islands: Lanzarote, Montañosa (H. van der Strate, Jan-1998) & AY055920.AY056011 \\
\hline & Cladophoropsis membranacea & CmMedSL & Syria: Lattakia & AY055880.AY055947 \\
\hline & Cladophoropsis membranacea & CmRS2 & Egypt: Sharm el Naga Bur Safaga & AY055878.AY055945 \\
\hline & Cladophoropsis membranacea & Soc318.F486 & Yemen: Socotra, Ras Qalansiya (F. Leliaert, 8-Mar-1999) & FN377614 \\
\hline \multirow[t]{16}{*}{ sp. 5} & Cladophoropsis membranacea & BW4 & Panama: near Isla Grande (Caribbean) (B. Wysor, 13-Feb-1999) & AF510120 \\
\hline & Cladophoropsis membranacea & CmBonLa & Bonaire: Lacbaai (Caribbean) (H. van der Strate, Feb-1997) & AY055870.AY055937 \\
\hline & Cladophoropsis membranacea & CmCurJT & Curaçao: Jan Thiel (H. van der Strate, Oct-1996) & AY055869.AY055936 \\
\hline & Cladophoropsis membranacea & CmCurW & Curaçao: Willemstad (H. van der Strate, Oct-1996) & AY055863.AY055930 \\
\hline & Cladophoropsis membranacea & CmCVISalPdL1 & Cape Verde Islands: Sal, Pedra da Lume (H. van der Strate, Jul-1998) & AY055896.AY055973 \\
\hline & Cladophoropsis membranacea & CmCVISalPdL2 & Cape Verde Islands: Sal, Pedra da Lume (H. van der Strate, Jul-1998) & AY055892.AY055969 \\
\hline & Cladophoropsis membranacea & CmCVISanTCV1 & Cape Verde Islands: São Tiago, Cidade Velha (H. van der Strate, Jul-1998) & AY055887.AY055962 \\
\hline & Cladophoropsis membranacea & CmCVISanTCV2 & Cape Verde Islands: São Tiago, Cidade Velha (H. van der Strate, Jul-1998) & AY055888.AY055963 \\
\hline & Cladophoropsis membranacea & CmVIStXBB & St. Croix: Boiler Bay & AY055862.AY055929 \\
\hline & Cladophoropsis membranacea & CmVIStXCB & St. Croix: Cane Bay & AY055861.AY055928 \\
\hline & $\begin{array}{l}\text { Cladophoropsis sundanensis / } \\
\text { membranacea }\end{array}$ & DML58207.F651 & Bahamas: Norman's Pond Cay (M. \& D. Littler, 1-Jul-1998) & FN377619 \\
\hline & $\begin{array}{l}\text { Cladophoropsis membranacea / } \\
\text { sundanensis }\end{array}$ & DML58215.F671 & Bahamas: Norman's Pond Cay (M. \& D. Littler, 1-Jul-1998) & FN377620 \\
\hline & Cladophoropsis membranacea & DML59461.F652 & Belize: Carrie Bow Cay (M. \& D. Littler) & FN377615 \\
\hline & Cladophoropsis macromeres & DML68113.F658 & Bahamas: Green Turle Cay (M. \& D. Littler) & FN377617 \\
\hline & Cladophoropsis membranacea & HV387.F179 & Jamaica: St. Ann Parish, St. Ann's Bay, Drax Hall (H. Verbruggen, 7-Mar-2003) & FN377618 \\
\hline & siphonous sp. (Florida) & West4296.F417 & USA: Florida, Key West (Gulf of Mexico) (H. Humm \& F. Ott, 1964) & FN377616 \\
\hline \multirow[t]{10}{*}{ sp. 6} & Phyllodictyon anastomosans & FL1010.F445 & Tanzania: Zanzibar, Nungwi (F. Leliaert, 21-Jul-2001) & FN377621 \\
\hline & Boodlea composita & FL923.F453 & Tanzania: Zanzibar, Matemwe (F. Leliaert, 14-Jul-2001) & FN377623 \\
\hline & Cladophoropsis vaucheriiformis & FL954A.F509 & Tanzania: Zanzibar, Matemwe (F. Leliaert, 16-Jul-2001) & FN377624 \\
\hline & Cladophoropsis vaucheriiformis & FL954B.F510 & Tanzania: Zanzibar, Matemwe (F. Leliaert, 16-Jul-2001) & FN377625 \\
\hline & Phyllodictyon anastomosans & FL959.F457 & Tanzania: Zanzibar, Chwaka (F. Leliaert, 17-Jul-2001) & FN377628 \\
\hline & Phyllodictyon anastomosans & FL966.F401 & Tanzania: Zanzibar, Chwaka (F. Leliaert, 17-Jul-2001) & AM779642 \\
\hline & Phyllodictyon anastomosans & FL985.F460 & Tanzania: Zanzibar, Uroa (F. Leliaert, 19-Jul-2001) & FN377626 \\
\hline & Cladophoropsis vaucheriiformis & FL989B.F461 & Tanzania: Zanzibar, Uroa (F. Leliaert, 19-Jul-2001) & FN377627 \\
\hline & Phyllodictyon anastomosans & FLsn2 & Tanzania: Zanzibar, Nungwi (F. Leliaert, 21-Jul-2001) & FN377622 \\
\hline & Cladophoropsis vaucheriiformis & HEC11135.F514 & Tanzania: Mafia, Chole Bay (E. Coppejans, 8-Jan-1996) & FN377629 \\
\hline sp. 7 & Boodlea siamensis & FL714.F449 & Tanzania: Zanzibar, Chwaka Bay (F. Leliaert, 31-Jul-1997) & AF510121 \\
\hline
\end{tabular}


Table S1 (continued)

\begin{tabular}{|c|c|c|c|c|}
\hline $\begin{array}{l}\text { Phylogenetic } \\
\text { species }\end{array}$ & Morphological group & Specimen number & Geographical origin (collector and date of collection) & $\begin{array}{l}\text { Genbank accession } \\
\text { number }\end{array}$ \\
\hline \multirow[t]{2}{*}{ sp. 7} & Phyllodictyon anastomosans & FL994 & Tanzania: Zanzibar, Chwaka (F. Leliaert, 20-Jul-2001) & AF510122 \\
\hline & Cladophoropsis vaucheriiformis & HEC11394.F515 & Tanzania: Pemba, Misali Island (E. Coppejans, 21-Jan-1996) & FN377632 \\
\hline \multirow[t]{12}{*}{ sp. 8} & Boodlea composita & FL1007.F443 & Tanzania: Zanzibar, Nungwi (F. Leliaert, 21-Jul-2001) & FN377634 \\
\hline & Boodlea composita & FL694.F446 & Tanzania: Zanzibar, Nungwi (F. Leliaert, 20-Jul-2001) & AF510123 \\
\hline & Boodlea composita & FL694B.F446 & Tanzania: Zanzibar, Nungwi (F. Leliaert, 25-Jul-1997) & FN377635 \\
\hline & Boodlea composita & FL702.F447 & Tanzania: Zanzibar, Nungwi (F. Leliaert, 26-Jul-1997) & FN377636 \\
\hline & Struveopsis siamensis & FL916.F396 & Tanzania: Mbudya Island, West coast (F. Leliaert, 11-Jul-2001) & AM850134 \\
\hline & Boodlea composita & FL950.F397 & Tanzania: Zanzibar, Matemwe (F. Leliaert, 16-Jul-2001) & AM779625 \\
\hline & Boodlea composita & FL986.F411 & Tanzania: Zanzibar, Uroa (F. Leliaert, 19-Jul-2001) & FN377641 \\
\hline & Cladophoropsis vaucheriiformis & FL989A.F105 & Tanzania: Zanzibar, Uroa (F. Leliaert, 19-Jul-2001) & FN377638 \\
\hline & Boodlea siamensis & FL999.F402 & Tanzania: Zanzibar, Nungwi (F. Leliaert, 21-Jul-2001) & FN377637 \\
\hline & Phyllodictyon sp. (Kenya) & HEC8669a.F159 & Kenya: Mombasa, Mwamba Beach (E. Coppejans, 5-Sep-1991) & FN377640 \\
\hline & Boodlea composita & ODC1668.F848 & Kenya: Chale Island (O. De Clerck, 5-Apr-2008) & FN377639 \\
\hline & Boodlea composita & ODC665.F471 & Tanzania: Mbudya Island (O. De Clerck, 11-Jul-1997) & FN377633 \\
\hline \multirow[t]{17}{*}{ sp. 9} & $\begin{array}{l}\text { Phyllodictyon anastomosans / } \\
\text { Boodlea siamensis }\end{array}$ & BW1116 & Panama: near Knapps Hole, Bocas del Toro (Caribbean) (B. Wysor, 16-Oct-1999) & AF510128 \\
\hline & $\begin{array}{l}\text { Phyllodictyon anastomosans / } \\
\text { Boodlea siamensis }\end{array}$ & BW1386 & Panama: Cayos Zapatilla, Bocas del Toro (Caribbean) (W. Kooistra, 21-Oct-1999) & AF510129 \\
\hline & Phyllodictyon anastomosans & BW1426 & $\begin{array}{l}\text { Panama: Isla Bastimentos mangrove cay, Bocas del Toro (Caribbean) (B. Wysor, 21- } \\
\text { Oct-1999) }\end{array}$ & AF510130 \\
\hline & Phyllodictyon anastomosans & BW747 & Panama: Galeta (STRI-Research Station), Colon (Caribbean) (B. Wysor, 20-Jun-1999) & AF510125 \\
\hline & Phyllodictyon anastomosans & BW847 & Panama: Galeta (STRI-Research Station, Colon (Caribbean) (W. Kooistra, 24-Jul-1999) & AF510126 \\
\hline & Boodlea siamensis & BW920 & Panama: Urraba Island (Pacific) (B. Wysor, 12-Aug-1999) & AF510127 \\
\hline & $\begin{array}{l}\text { Phyllodictyon anastomosans / } \\
\text { Boodlea siamensis }\end{array}$ & BW95 & Panama: Randolph, Colon (Caribbean) (B. Wysor, 6-Mar-1999) & AF510124 \\
\hline & Phyllodictyon anastomosans & BWsn & Panama: Colombia (Caribbean) (G. Bula-Meyer, 2001) & AF510131 \\
\hline & Phyllodictyon anastomosans & BWsn & USA: Florida, Middle Grounds (Gulf of Mexico) (G. Meade, Aug-2000) & AF510133 \\
\hline & Phyllodictyon anastomosans & BWsn & Australia: Queensland, Great Barrier Reef, Cape Tribulation (W. Kooistra, 3-Jul-2001) & AF510132 \\
\hline & Phyllodictyon anastomosans & DJ6608 & Ghana: Ghana (D. John, 26-Jan-1971) & AF510135 \\
\hline & Phyllodictyon anastomosans & DJ9274 & Gambia: North of Fajara Hotel, Gambia River Estuary, Gambia (D. John, 16-Nov-1975) & AF510134 \\
\hline & Boodlea siamensis & DML64212.F655 & Panama: Isla Escudo de Veraguas (Caribbean) (M. \& D. Littler) & FN377644 \\
\hline & Phyllodictyon anastomosans & DML68772.F693 & Belize (M. \& D. Littler) & FN377642 \\
\hline & Phyllodictyon anastomosans & SaBra & Brazil & Kooistra et al. 1993 \\
\hline & Phyllodictyon anastomosans & SaMB & St. Croix: Malta Baths (W. Kooistra) & AM779641 \\
\hline & Phyllodictyon anastomosans & USJA73440.F581 & Costa Rica & FN377643 \\
\hline \multirow[t]{10}{*}{ sp. 10} & Phyllodictyon anastomosans & BW1078 & Panama: Isla Grande (Caribbean) (B. Wysor, 27-Jul-1999) & AF510137 \\
\hline & Phyllodictyon anastomosans & BW304 & Panama: Isla Mamey, Colon (Caribbean) (B. Wysor, 27-Jul-1990) & AF510138 \\
\hline & Boodlea siamensis & BWsn2 & USA: Hawaii, Oahu, Kupikipikio Point (P. Vroom, 8-May-2001) & AF510140 \\
\hline & Boodlea montagnei & CP13133 & $\begin{array}{l}\text { Papua New Guinea: Madang, Kranket Island (E. Coppejans \& W. Prud'homme van } \\
\text { Reine, 13-Jul-1990) }\end{array}$ & AF510139 \\
\hline & Phyllodictyon anastomosans & CP13441 & $\begin{array}{l}\text { Papua: Madang, N of Wongat Island (E. Coppejans \& W. Prud'homme van Reine, 27- } \\
\text { Jul-1990) }\end{array}$ & AF510136 \\
\hline & Boodlea siamensis & DML40014.F576 & Fiji: Dravuni Island (M. \& D. Littler) & FN377673 \\
\hline & Boodlea siamensis & DML40109.F583 & Fiji: Alacrity Rock (M. \& D. Littler) & FN377671 \\
\hline & Boodlea siamensis & DML40381.F584 & Fiji: E Yaukuve Island (M. \& D. Littler, 11-Mar-1996) & FN377672 \\
\hline & Boodlea siamensis & DML68460.F635 & Bonaire (M. \& D. Littler) & FN377645 \\
\hline & Boodlea composita & FL1089.F759 & Philippines: Negros Oriental, Dumaguete (F. Leliaert, 12-Sep-2007) & FN377654 \\
\hline
\end{tabular}


Table S1 (continued)

\begin{tabular}{|c|c|c|c|c|}
\hline $\begin{array}{l}\text { Phylogenetic } \\
\text { species }\end{array}$ & Morphological group & Specimen number & Geographical origin (collector and date of collection) & $\begin{array}{l}\text { Genbank accession } \\
\text { number }\end{array}$ \\
\hline \multirow[t]{25}{*}{ sp. 10} & Boodlea siamensis & FL1090.F760 & Philippines: Negros Oriental, Dumaguete (F. Leliaert, 12-Sep-2007) & FN377655 \\
\hline & Phyllodictyon anastomosans & FL1109.F761 & Philippines: Negros Oriental, Dumaguete (F. Leliaert, 14-Sep-2007) & FN377656 \\
\hline & Boodlea siamensis & FL1110.F762 & Philippines: Negros Oriental, Dumaguete (F. Leliaert, 14-Sep-2007) & FN377657 \\
\hline & Boodlea composita & FL1111.F763 & Philippines: Negros Oriental, Dumaguete (F. Leliaert, 14-Sep-2007) & FN377658 \\
\hline & Boodlea composita & FL1184.F841 & Philippines: Mactan Island, Buyong Mactan (F. Leliaert, 20-Sep-2007) & FN377669 \\
\hline & Phyllodictyon anastomosans & FL1185.F773 & Philippines: Mactan Island, Buyong Mactan (F. Leliaert, 20-Sep-2007) & FN377670 \\
\hline & Cladophoropsis philippinensis & HV710.F176 & Philippines: Bohol, Panglao (H. Verbruggen, 1-Feb-2004) & AM779639 \\
\hline & Boodlea siamensis & HV864.F343 & Philippines: Mactan Island (H. Verbruggen, 16-Feb-2004) & FN377660 \\
\hline & Boodlea siamensis & HV865.F344 & Philippines: Mactan Island (H. Verbruggen, 16-Feb-2004) & FN377661 \\
\hline & Boodlea siamensis & HV867.F346 & Philippines: Mactan Island (H. Verbruggen, 16-Feb-2004) & FN377662 \\
\hline & Boodlea composita & HV868.F347 & Philippines: Mactan Island (H. Verbruggen, 16-Feb-2004) & FN377663 \\
\hline & Boodlea siamensis & HV869.F348 & Philippines: Mactan Island (H. Verbruggen, 16-Feb-2004) & FN377664 \\
\hline & Boodlea siamensis & HV870.F349 & Philippines: Mactan Island (H. Verbruggen, 16-Feb-2004) & AM779626 \\
\hline & Boodlea sp. (Indonesia) & L0654201.F614 & $\begin{array}{l}\text { Indonesia: Borneo, Berau Archipelago, Kakaban Island (L. de Senerpont Domis \& W. } \\
\text { Prud'homme van Reine, 6-Oct-2003) }\end{array}$ & FN377650 \\
\hline & Boodlea sp. (Indonesia) & L0654202.F615 & $\begin{array}{l}\text { Indonesia: Borneo, Berau Archipelago, Kakaban Island (L. de Senerpont Domis \& W. } \\
\text { Prud'homme van Reine, 6-Oct-2003) }\end{array}$ & FN377651 \\
\hline & Boodlea sp. (Indonesia) & L0654203.F616 & $\begin{array}{l}\text { Indonesia: Borneo, Berau Archipelago, Kakaban Island (L. de Senerpont Domis \& W. } \\
\text { Prud'homme van Reine, 6-Oct-2003) }\end{array}$ & FN377652 \\
\hline & Boodlea siamensis & NP154 & Hawaii: Oahu, Waikiki, San Souci Beach (N. Phillips, 10-May-1992) & AF510141 \\
\hline & Boodlea siamensis & PH171.F472 & Philippines: Mactan Island (F. Leliaert, 12-Aug-1998) & FN377665 \\
\hline & Boodlea composita & PH646.F479 & Philippines: Mactan Island (F. Leliaert, 6-Aug-1998) & FN377667 \\
\hline & Boodlea composita & PH648.F480 & Philippines: Mactan Island (F. Leliaert, 6-Aug-1998) & FN377668 \\
\hline & Phyllodictyon anastomosans & SaGua & Guam & Kooistra et al. 1993 \\
\hline & Boodlea siamensis & SOC201.F482 & Yemen: Socotra, Siqirah (F. Leliaert, 24-Feb-1999) & FN377646 \\
\hline & Boodlea siamensis & SOC204.F312 & Yemen: Socotra (F. Leliaert, 24-Feb-1999) & FN377647 \\
\hline & Boodlea siamensis & SOC226.F483 & Yemen: Socotra, Qadub, Dihamd (F. Leliaert, 26-Feb-1999) & FN377649 \\
\hline & Boodlea siamensis & SOC254.F408 & Yemen: Socotra, Nojid, Rhiy di-Qatanhin (F. Leliaert, 4-Mar-1999) & FN377648 \\
\hline \multirow[t]{3}{*}{ sp. 11} & Cladophoropsis sundanensis & FL901.F451 & Tanzania: Kunduchi (F. Leliaert, 10-Jul-2001) & FN377675 \\
\hline & Cladophoropsis sundanensis & HEC12976.F189 & Tanzania: Mtwara, Mana Hawanja (E. Coppejans, 29-Jul-2000) & AM779640 \\
\hline & Cladophoropsis sundanensis & KZN2148.F470 & Africa: Sodwana Bay, Quarter Mile Reef (F. Leliaert, 11-Feb-2004) & FN377674 \\
\hline sp. 12 & Cladophoropsis membranacea & Tittley301.F494 & Thailand: Kamphuan Koh Ra (I. Tittley, 10-Nov-2001) & FN377676 \\
\hline \multirow[t]{8}{*}{ sp. 13} & Cladophoropsis sundanensis & BW1080 & Panama: Isla Grande (Caribbean) (B. Wysor, 7-Oct-1999) & AF510142 \\
\hline & Cladophoropsis sundanensis & Cleary509532.F370 & Indonesia: Onrus (Cleary, 7-Sep-2005) & FN377682 \\
\hline & Cladophoropsis sundanensis & CsBon & Bonaire: Hato & Kooistra et al. 1993 \\
\hline & Cladophoropsis sundanensis & CsGua & Guam: Pago Bay & Kooistra et al. 1993 \\
\hline & Cladophoropsis sundanensis & Draisma509051.F368 & Indonesia: Damar kecil (S. Draisma, 8-Sep-2005) & FN377684 \\
\hline & Cladophoropsis sundanensis & FL1119.F765 & Philippines: Siquijor, Sawang (F. Leliaert, 15-Sep-2007) & FN377685 \\
\hline & Cladophoropsis sundanensis & FL1182.F772 & Philippines: Mactan Island, Buyong Mactan (F. Leliaert, 20-Sep-2007) & FN377686 \\
\hline & Cladophoropsis sundanensis & FL1186.F842 & Philippines: Mactan Island, Buyong Mactan (F. Leliaert, 20-Sep-2007) & FN377687 \\
\hline
\end{tabular}


Table S1 (continued)

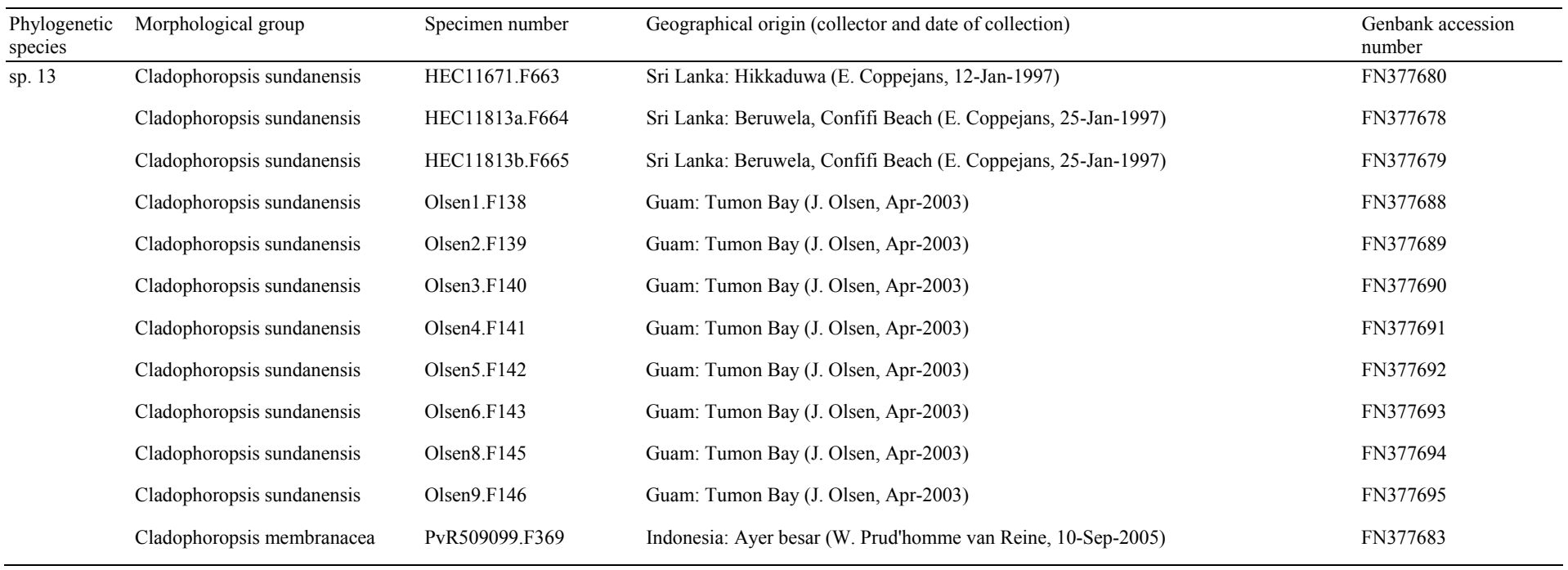


Table S2

Primer sequences used to amplify the nrDNA ITS1-5.8S-ITS2 region.

\begin{tabular}{llll}
\hline Primer name & Direction & Sequence in 5'-3' direction & Target \\
\hline ITS1FL & forward & CCTGCGGAGGGATCCATAGC & 3'-end of SSU rDNA \\
Pana1FL & forward & CGATTGGGTGTGCTGGTGAAATG & 3'-end of SSU rDNA \\
ITS2FL & reverse & GCTGCGTTCTTCATCGATGTGG & 5.8S rDNA \\
ITS3FL & forward & CCACATCGATGAAGAACGCAGC & 5.8S rDNA \\
Pana4FL & reverse & GTTCAGCGGGTGTCCCTG & 5'-end of LSU rDNA \\
Pana5FL & reverse & GGGTGTCCCTGCCTGAAC & 5'-end of LSU rDNA
\end{tabular}

\section{Table S3}

Pairwise sequence divergence (minimum and maximum uncorrected p-distances) within species (bold) and main clades (grey), and between clades.

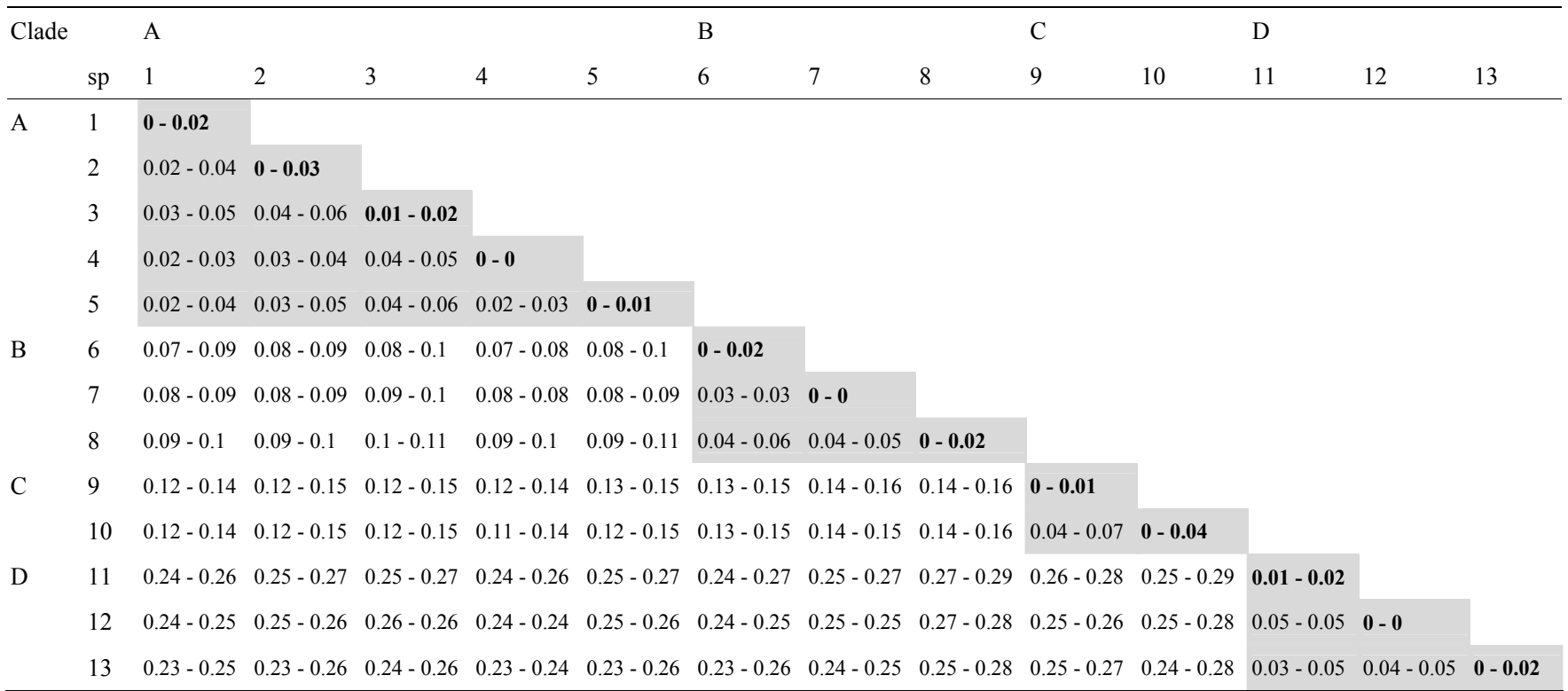

